\title{
Towards the proteome of the marine bacterium Rhodopirellula baltica: Mapping the soluble proteins
}

\author{
Dörte Gade ${ }^{1}$, Dorothea Theiss ${ }^{2}$, Daniela Lange ${ }^{1}$, Ekaterina Mirgorodskaya $^{2}$, \\ Thierry Lombardot ${ }^{1}$, Frank Oliver Glöckner ${ }^{1}$, Michael Kube ${ }^{2}$, \\ Richard Reinhardt ${ }^{2}$, Rudolf Amann ${ }^{1}$, Hans Lehrach ${ }^{2}$, Ralf Rabus ${ }^{1}$ and Johan Gobom ${ }^{2}$ \\ ${ }^{1}$ Max Planck Institute for Marine Microbiology, Bremen, Germany \\ ${ }^{2}$ Max Planck Institute for Molecular Genetics, Berlin, Germany
}

The marine bacterium Rhodopirellula baltica, a member of the phylum Planctomycetes, has distinct morphological properties and contributes to remineralization of biomass in the natural environment. On the basis of its recently determined complete genome we investigated its proteome by 2-DE and established a reference 2-DE gel for the soluble protein fraction. Approximately 1000 protein spots were excised from a colloidal Coomassie-stained gel (pH 4-7), analyzed by MALDI-MS and identified by PMF. The non-redundant data set contained 626 distinct protein spots, corresponding to 558 different genes. The identified proteins were classified into role categories according to their predicted functions. The experimentally determined and the theoretically predicted proteomes were compared. Proteins, which were most abundant in 2-DE gels and the coding genes of which were also predicted to be highly expressed, could be linked mainly to housekeeping functions in glycolysis, tricarboxic acid cycle, amino acid biosynthesis, protein quality control and translation. Absence of predictable signal peptides indicated a localization of these proteins in the intracellular compartment, the pirellulosome. Among the identified proteins, 146 contained a predicted signal peptide suggesting their translocation. Some proteins were detected in more than one spot on the gel, indicating post-translational modification. In addition to identifying proteins present in the published sequence database for R. baltica, an alternative approach was used, in which the mass spectrometric data was searched against a maximal ORF set, allowing the identification of four previously unpredicted ORFs. The 2-DE reference map presented here will serve as framework for further experiments to study differential gene expression of $R$. baltica in response to external stimuli or cellular development and compartmentalization.

Keywords:

MALDI-MS / PMF / Rhodopirellula baltica / 2-DE

\section{Introduction}

Since the pioneering determination of the Haemophilus influenzae [1] and Mycoplasma pneumoniae [2] genomes, more than 250 complete genomes from bacteria have been reported (for

Correspondence: Dr. Ralf Rabus, Max Planck Institute for Marine Microbiology, Celsiusstr. 1, D-28359 Bremen, Germany

E-mail: rrabus@mpi-bremen.de

Fax: +49-421-2028-580
Received: September 1, 2004

Revised: November 16, 2004

Accepted: December 14, 2004 detailed information see e.g., www.genomesonline.org). Even though a given genome represents the blueprint of life, there is a need for functional analysis on the transcriptional and proteomic level in order to define (i) which of the predicted genes can be expressed in principle, and (ii) the physiological conditions inducing their expression. In contrast to the numerous publicly available genome sequences, only few proteomes (protein maps) have been reported to date. Moreover, only a limited number of proteins is usually identified and annotated. Among the comprehensive protein maps are 
those for the very well-studied standard bacteria Escherichia coli [3-5] and Bacillus subtilis [6, 7], some pathogens like, e.g., Mycoplasma pneumoniae [8-10], Staphylococcus aureus [11, 12], Haemophilus influenzae [13-15] and Pseudomonas aeruginosa [16], and some biotechnologically relevant bacteria such as Corynebacterium glutamicum [17] and Streptomyces coelicolor [18].

Protein maps are most often constructed by applying 2$\mathrm{DE}$ in combination with MS analysis. 2-DE is a well-established technique for high-resolution separation of proteins from complex mixtures [19]. Electrophoretically separated proteins are excised from stained 2-DE gels and cleaved enzymatically (e.g., by trypsin) to defined fragments. The masses of the generated peptides, determined by MS, constitute a PMF of the protein. For protein identification, the PMF is compared to sets of masses calculated for each protein sequence in a database, based on the known cleavage specificity of the protease used [20-22]. MALDI-MS [23] has become the most widely used technique for protein identification. Automation allows a high throughput at the level of spot excision, sample processing and MS analysis.

Over the last one to two decades, the impact of microbial activity on environmental processes has been increasingly recognized. This led recently to the initiation of genome projects on environmentally relevant bacteria. Genomes of such bacteria in conjunction with functional analysis will provide new insights into the molecular basis of microbial activity (and its control) in the natural environment. The first examples are the complete genome sequences of Synechocystis sp. [24] (www.kazusa.or.jp), Caulobacter crescentus [25] (www.tigr.org) and Rhodopirellula baltica [26] (www.regx.de). With 7.145 Mb and $7325 \mathrm{ORF}$, the genome of $R$. baltica represents one of the largest bacterial genomes sequenced so far. In the case of $C$. crescentus, a protein map with 295 identified proteins has only very recently been reported [27], whereas 57 membrane proteins were identified from Synechocystis sp. strain PCC6803 [28]. $R$. baltica is a marine, aerobic bacterium that has been isolated from the Baltic Sea. It belongs to the phylogenetic distinct group of Planctomycetes [29], members of which are known to be globally distributed and suggested to be involved in carbon remineralization. Interest in this group of bacteria also comes from their unusual morphological properties. The cells reproduce via budding and display a complex life cycle. $R$. baltica cells can occur in two morphotypes, i.e., as single motile cells or attached to each other in aggregates. Peptidoglycans appear to be absent from the proteinaceous cell wall. Individual cells are organized in membrane-defined compartments including a membraneengulfed nucleoid, termed pirellulosome [30, 31].

To study molecular physiology, cellular development and compartmentalization of this bacterium, we established a 2$\mathrm{DE}$ map of soluble proteins in the $\mathrm{pH}$ range of 4 to 7 . The master gel contains 626 annotated proteins, which were identified by PMF.

\section{Materials and methods}

\subsection{Growth of cells and preparation of soluble proteins}

Cells of $R$. baltica (DSM 10527) were grown in mineral medium with ribose $(10 \mathrm{~mm})$, glucose $(10 \mathrm{~mm})$ or $N$-acetylglucosamine (10 $\mathrm{mm}$ ) as sole source of organic carbon [32]. Harvesting of cells was essentially performed as previously described [32]. Cells were harvested in the exponential growth phase by centrifugation $\left(10000 \times \mathrm{g}, 15 \mathrm{~min}, 4^{\circ} \mathrm{C}\right)$. The pellets were washed with $100 \mathrm{~mm}$ Tris/ $\mathrm{HCl} \mathrm{pH} 7.5$ containing $5 \mathrm{mM} \mathrm{MgCl}_{2}$. Cell pellets were directly frozen in liquid nitrogen and stored at $-80^{\circ} \mathrm{C}$ until cell breakage and 2-DE. Prior to cell breakage, pellets were resuspended in $1 \mathrm{~mL}$ lysis buffer (7 $\mathrm{m}$ urea, $2 \mathrm{~m}$ thiourea, 2\% DTT, 2\% CHAPS, $0.5 \%$ carrier ampholytes; Amersham Biosciences, Freiburg, Germany). Cell breakage was performed with the PlusOne ${ }^{\circledR}$ grinding kit (Amersham Biosciences) following the manufacturer's instructions. Removal of cell debris, DNA and membranes by centrifugation $(100000 \times \mathrm{g}$, $1 \mathrm{~h}, 15^{\circ} \mathrm{C}$ ) yielded the fraction of soluble proteins. The protein content of this fraction was determined using the method described by Bradford [33].

\subsection{2-DE, staining, and image acquisition}

2-DE was essentially performed as described before [19, 32, 34]. In brief, IEF was performed using the IPGphor ${ }^{\mathrm{TM}}$ system and $24 \mathrm{~cm}$ long IPG strips (linear $\mathrm{pH}$ gradient from 4 to 7; Amersham Biosciences), followed by equilibration of the gels with DTT and iodoacetamide. The second dimension separation was then performed using the $\operatorname{Ettan}^{\mathrm{TM}}$ Dalt system (Amersham Biosciences) and gels made of $375 \mathrm{~mm}$ Tris/ $\mathrm{HCl}, 0.1 \% \mathrm{SDS}$ and $12.5 \%$ Duracryl (Genomic Solutions, Ann Arbor, Michigan, USA). The protein load for preparative gels was $400 \mu \mathrm{g}$. Proteins were visualized using colloidal Coomassie (method modified from [35]). For image acquisition the gels were digitalized with the Image Scanner (Amersham Biosciences).

\subsection{Gel sample excision and processing}

Excision and processing of the gel samples for PMF was performed as described previously [36], with some modifications. Protein spots were sampled from the gel using an automatic excision workstation (Proteineer; Bruker Daltonics, Bremen, Germany). The excision head was equipped with a single needle with a diameter of $2 \mathrm{~mm}$. The excised gel spots were delivered into 96-well polypropylene microtiter plates (MTP) (Costar Thermowell ${ }^{\circledR}$, Cornis, NY, USA), pre-treated by punching two holes $(\mathrm{d}<0.5 \mathrm{~mm})$ in the bottom of each well. This preparation allows removal of the washing solutions and reagents used throughout the digestion procedure by simple flow-through centrifugation, while retaining the gel particles in the wells. To protect the pierced 
96-well MTP from environmental contamination, they were placed in a second 96-well MTP and covered by a lid. The second MTP also serves as collector for liquid removed by centrifugation. To ensure that no liquid from the collection MTP reaches or contaminates the pierced MTP, a spacer was placed between these two MTP. Following excision, all liquid was removed from the gel pieces by centrifugation and the sample plates were stored at $-80^{\circ} \mathrm{C}$ prior to further processing.

Prior to digestion the gel particles were washed by incubation for $2 \times 30 \mathrm{~min}$ in $100 \mu \mathrm{L} \mathrm{50 \%} \mathrm{ethanol} \mathrm{v/v.} \mathrm{Following}$ removal of the washing solution by centrifugation, residual water was expelled from the gel particles by incubation for $5 \mathrm{~min}$ in $100 \%$ ethanol. The sample plates were then placed without lid in a laminar flow-bench for $15 \mathrm{~min}$ to allow evaporation of the ethanol. An aliquot of freshly prepared, cooled trypsin (Roche, recombinant porcine) solution $(5 \mu \mathrm{L}$, $10 \mathrm{ng} / \mu \mathrm{L}, 50 \mathrm{~mm} \mathrm{NH}_{4} \mathrm{HCO}_{3}, \mathrm{pH} 7.8$ ) was added to each sample. The sample plates were immediately placed in a refrigerator and incubated at $4^{\circ} \mathrm{C}$ for $30 \mathrm{~min}$. Thereafter, an aliquot of digestion buffer $\left(50 \mathrm{~mm} \mathrm{NH} \mathrm{NHCO}_{3}, \mathrm{pH}\right.$ 7.8) was added to each sample, and the MTP were placed in a humidified box and incubated for $4 \mathrm{~h}$ at $37^{\circ} \mathrm{C}$.

\subsection{MALDI-MS}

Protein digests were prepared for MALDI using the $\alpha$-cyano4-hydroxycinnamic acid affinity sample preparation technique described previously [37]. Mass analysis of positively charged ions was performed on an Ultraflex LIFT and a Reflex III instrument (Bruker Daltonics) operated in the reflector mode and using delayed ion extraction. Positively charged ions in the mass range 700-3 500 Da were analyzed.

\subsection{Data processing and protein identification}

The success rate and confidence of protein identification by PMF depends to a high degree on the accuracy of the mass measurement. High mass accuracy by MALDI-TOF MS was achieved by using internal reference compounds for spectra calibration. To calibrate the large number of spectra acquired in this study, the following procedure was developed. First, the acquired MALDI-TOF spectra were calibrated externally using a polynomial function according to a previously described procedure [38]. This calibration ensures a maximum error of $500 \mathrm{ppm}$ over the entire MALDI sample support. For a subsequent internal mass correction, each spectrum was searched for signals corresponding to known reference compounds. Three peptides (Angiotensin I, $\mathrm{MH}^{+}$ 1296.68; Neurotensin 1-13, $\mathrm{MH}^{+} 1$ 672.9150; ACTH 18-39, $\mathrm{MH}^{+} 2$ 465.1989; monoisotopic mass values), which were mixed into the MALDI matrix solution, and two abundant signals corresponding to trypsin autoproteolysis $\left(\mathrm{MH}^{+}\right.$ 842510 and 2 211.1045, respectively) were used as internal references. For the spectra in which at least three of these compounds were detected, a linear regression of the relative errors for the reference signals versus their calculated $\mathrm{m} / \mathrm{z}$ values was determined. If the standard deviation of the regression line was below $10 \mathrm{ppm}$, the regression function was used for correction of the externally calibrated mass values. If a detected calibrant had a relative error $>2$ SD it was discarded and the linear regression calculated again.

In some cases a sufficient number of reference masses was not detected, and in other cases, an analyte signal with a molecular mass close to the reference compound was erroneously selected as a calibrant. For example, an analyte signal that partially overlapped with the trypsin autoproteolysis signal of $m / z 842510$ was erroneously selected as a calibrant. The resulting standard deviation of the linear regression was $17.7 \mathrm{ppm}$, and the calibration thus discarded. Out of 384 spectra acquired on one MALDI sample support, 190 fulfilled the criteria for internal mass correction. The remaining 194 spectra were calibrated with background signals of unknown identity, as follows: using the internally calibrated spectra, a histogram was constructed of the abundance of signals with mass differences within $\Delta m / z 0.05$. Mass values within this interval, detected in $>25$ spectra in the data set were averaged and added to the list of reference masses. Using the new list of internal reference masses, the internal correction procedure was repeated with the remaining 194 spectra, this time with the requirement that at least six signals in each spectrum should match values in the calibrant list. Following this second round of internal correction, all the remaining spectra were successfully calibrated.

The presence of background signals in the spectra decreases the specificity of the database search. Background signals were assigned as described in the previous section, and removed from the data set. In addition, sodium- and potassium-cationized molecular ions, appearing as satellite signals to the protonated peptide molecular ion signal with $\Delta m / z 21982$ and 38.090, respectively, were removed.

Database searching was performed using the software MASCOT (Matrix Science, London, UK) [39]. The published ORF set of R. baltica (BX119912) was searched using the following settings: mass error tolerance: $50 \mathrm{ppm}$; fixed modifications: Cys-carbamidomethylation; variable modifications: oxidation; one tolerated missed cleavage. Under these conditions, a probability based MOWSE score $>51$ was considered significant $(p<0.05)$.

\subsection{Generation of theoretical 2-DE gels}

The published ORF set of R. baltica (Acc. BX119912) was used to create the theoretical 2-DE gels. $M_{\mathrm{r}}$ and $\mathrm{p} I$ were calculated for each predicted protein using the program pepstats from emboss (www.hgmp.mrc.ac.uk/Software/EMBOSS) [40]. The annotation of the published ORF set was scanned for the keywords "conserved hypothetical" and "hypothetical" in the product key of the description, generating the conserved hypothetical and hypothetical groups. The remaining proteins were sorted into the group assigned function. 


\subsection{Construction of a maximal ORF set}

In order to identify proteins encoded by genes that are not present in the published ORF set of R. baltica (BX119912), the following strategy was employed. Based on the genomic sequence of $R$. baltica, a new ORF set was constructed by means of a PERL script according to the following steps. First, the positions of all stop codons in the genome were determined. For each stop codon, all theoretically possible reading lengths with a minimal ORF length of 102 bases were calculated by extending their sequences from the stop codon to all possible start codons detectable until the next stop codon. The resulting ORF list, denoted Maximum ORF Set (MOS), comprised 578949 sequences and represents the maximal coding capacity of the genome. The MOS was translated into amino acid sequences and used as database for protein identification by PMF using data from all three analyzed 2-DE gels, as described in the Section 3.

\subsection{Signal peptides and gene expression levels predictions}

Signal peptides were predicted by analyzing each theoretical protein encoded by the $R$. baltica genome with the program SignalP 2.0 [41]. From this data set proteins were extracted which corresponded to identified 2-DE-separated proteins by means of a custom PERL script (using the GenDB system) [42]. Proteins with SignalP scores $>0.75$ were considered as potentially translocated. Expression level prediction based on codon usage optimization was calculated for each gene in the $R$. baltica genome according to the method described by Karlin et al. [43]. Highly expressed reference genes including ribosomal proteins, translation factors and chaperonins were extracted from the published annotation of $R$. baltica [26].

\section{Results and discussion}

\subsection{Comparison of theoretical and experimental proteome}

Three different theoretical proteome maps of R. baltica were created: one for proteins with "assigned function" (Fig. 1A), one for "conserved hypothetical" proteins (Fig. 1B) and one for "hypothetical proteins" (Fig. 1C). Proteins with assigned function are homologous to proteins with known functions. Conserved hypothetical proteins cannot be assigned to any function, however they have homologs in genomes of other organisms. Hypothetical proteins are also of unknown function, but they are to date not known from any organism other than $R$. baltica.

An overlay of these three maps represents the complete theoretical proteome map predicted from the annotated genome sequence. Remarkably, it shows a different isoelectric distribution pattern than those of previously reported bacterial and archaeal proteomes [44, 45]. Typically, prokaryotic theoretical proteome maps display a bimodal distribution with two protein-rich areas in the acidic and alkaline ranges, separated by a pronounced protein-depleted area around $\mathrm{pH}$ 7. In contrast, $R$. baltica displays a trimodal distribution with a third area of protein abundance in the neutral range. A protein peak around $\mathrm{pH} 7$ has previously only been described for eukaryotic proteomes [45]. It is assumed that the bi- or trimodality of protein $\mathrm{p} I$ reflects the subcellular localization of the proteins. While cytoplasmic proteins typically have $\mathrm{p} I$ values of around 5, integral membrane proteins tend to have $\mathrm{p} I$ values of around 9. Proteins belonging to these two groups can be found in all genomes in large numbers. The nuclear proteins apparently form the third cluster in eukaryotic proteomes [45]. While a large number of proteins with neutral $\mathrm{p} I$ are predicted, the analyzed 2-DE gel (Fig. 1D-F, Fig. 2B and D) reveals only a limited number of proteins close to $\mathrm{pH} 7$. Notably, the theoretical proteome of $R$. baltica contains a large number of predicted proteins with pI higher than 10, while the alkaline proteins of well-studied bacteria such as E. coli center around pI 9 .

Functions could be assigned to only $32 \%$ of the predicted proteins of $R$. baltica. Out of these, the majority is predicted to fall into the acidic region of the theoretical 2-DE gel. Thus, the applied IEF conditions are apparently well suited to study this group of proteins. For the conserved hypothetical proteins (amounting to $14 \%$ of the predicted proteins) a similar situation was observed.

More than half (54\%) of all predicted proteins belong to the hypothetical proteins, which are unique to $R$. baltica. However, these proteins are apparently under-represented in the set of proteins identified in this study. The theoretical 2DE gel displayed in Fig. $1 \mathrm{C}$ reveals that the majority of hypothetical proteins have theoretical pI above 7, in fact, $37 \%$ of them have $\mathrm{p} I$ of greater than 10 . Since a $\mathrm{pH}$ gradient from 4 to 7 was used in this study, these alkaline proteins could not be detected. Remarkably, many of the predicted alkaline proteins have rather low molecular mass (below $10 \mathrm{kDa}$ ), probably hampering their isolation by conventional 2-DE. A contribution of ORF overprediction to the high number of hypothetical proteins cannot be excluded at present. Nevertheless, it is tempting to speculate that $R$. baltica recruits hypothetical proteins for specific functions, e.g., in cellular development or translocation of proteins and solutes across the complex membrane structure.

\subsection{Master gel}

The soluble protein fraction of $R$. baltica grown under standard conditions was visualized using 2-DE with immobilized $\mathrm{pH}$ gradients from 4 to 7 . This fraction should represent the major part of the cytosolic proteins. Under these conditions, approximately 2000 proteins of $R$. baltica can be separated and detected, when highly sensitive protein stains such as silver or fluorescent dyes are applied (see accom- 

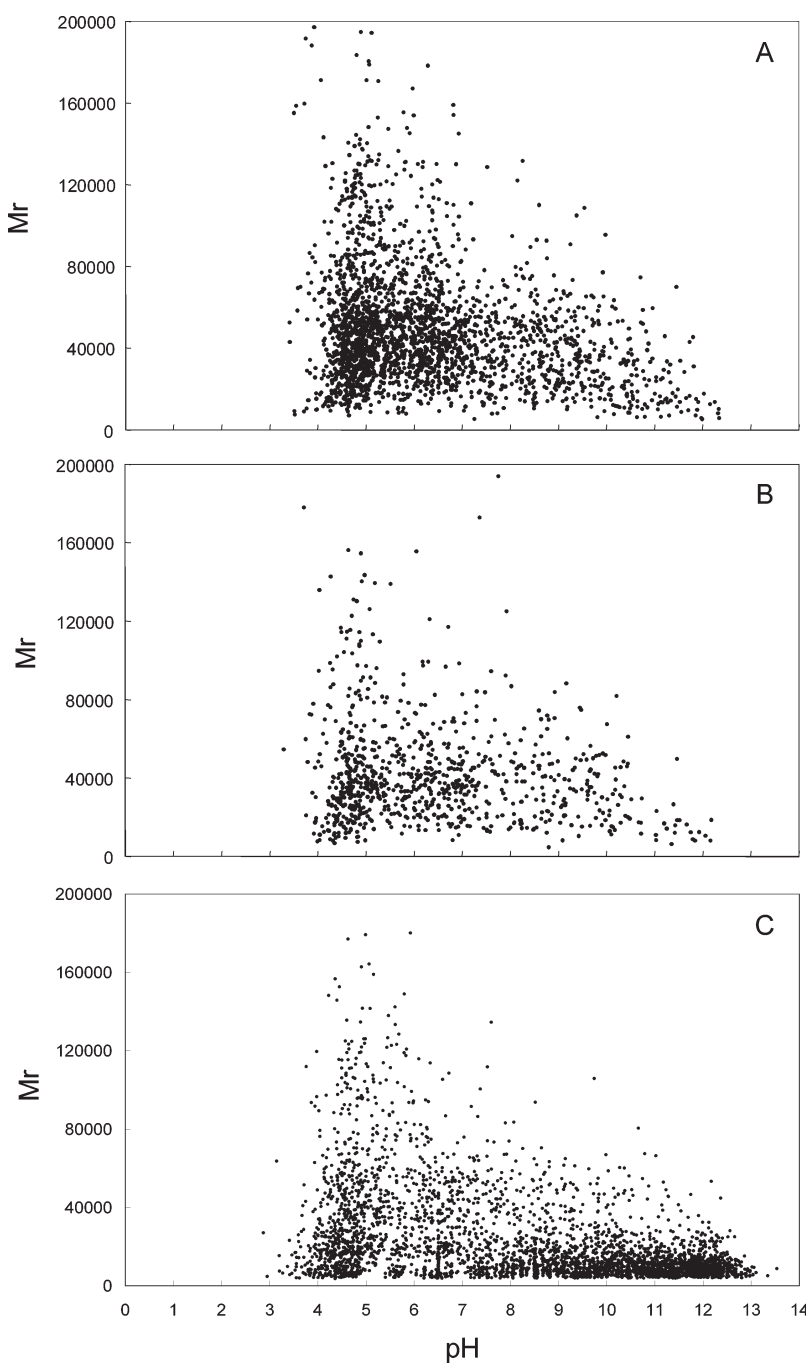
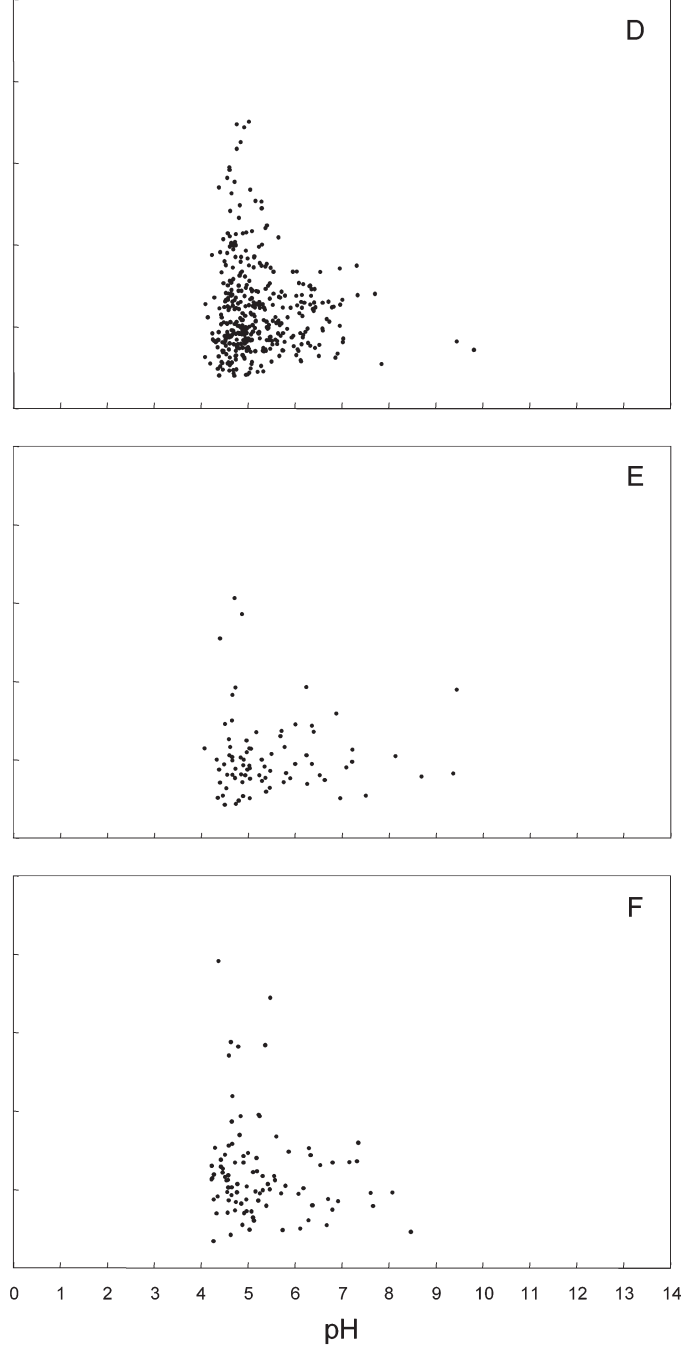

Figure 1. Theoretical 2-DE gels of proteins predicted from the genome of $R$. baltica $(A-C)$ and the subset of proteins experimentally identified in this study (D-F). Isoelectric points and molecular weights were calculated using the "pepstats" program module of emboss. Proteins with functional assignment ( $A$ and $D)$, conserved hypothetical proteins ( $B$ and $E)$, hypothetical proteins $(C$ and $F)$.

panying publication). Figure 2A-D show the colloidal Coomassie-stained master gel from $R$. baltica cells grown with ribose. From the approximately 1000 excised gel samples, 626 proteins, represented by different spots on the gel, were identified by means of PMF $(p<0.05)$. Since some 30 proteins occurred as at least two spots, the actual number of distinct identified ORFs amounted to 558. The identified proteins were annotated in the master gel sections with the published gene numbers (Fig. 2A-D) and grouped according to functional categories (Table 1). Predicted functions of each identified protein are given in Table 2 . To verify the identifications of the master gel, 2-DE and MS analysis of cells grown with glucose and $\mathrm{N}$-acetylglucosamine, respectively, were analyzed in parallel (Table 2). Among the 558 identified gene products 301 (54\%) were identified from at least two independent 2-DE gels.
Newly developed software was used for processing of the calibrated mass spectrometric data. This included filtering of sodium and potassium adduct signals, filtering of non-peptidederived masses, filtering of signals derived from known contaminants such as trypsin autoproteolysis products, and statistical filtering of frequently occurring $m / z$ values representing unknown gel sample contaminants. This processing improves the quality of the input data for the database search, thereby increasing the number of identified proteins and their respective scores. For example, in a subset of 384 samples prepared on one MALDI target, 205 spectra (53\%) resulted in a significant identification score when filtering of the data was not applied. With filtering, the number of significant identification results increased to 262 (68\%). Concomitantly, the average MOWSE score of the identified proteins increased from 99 to 119 , thereby improving the certainty of the identification results. 
$\mathrm{p} / 4.0$

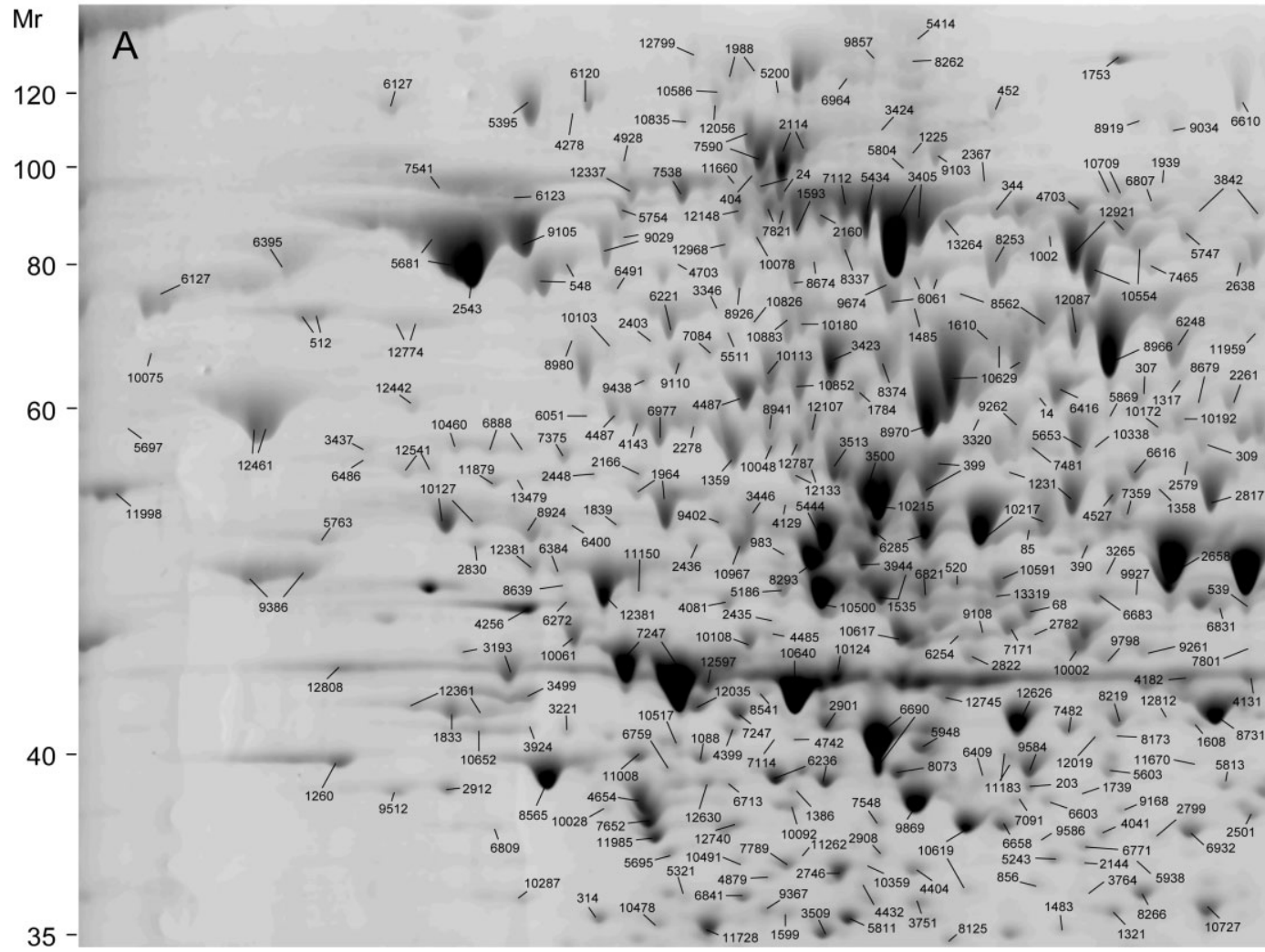
$\mathrm{p} / 5.5$
6.0
6.5
7.0

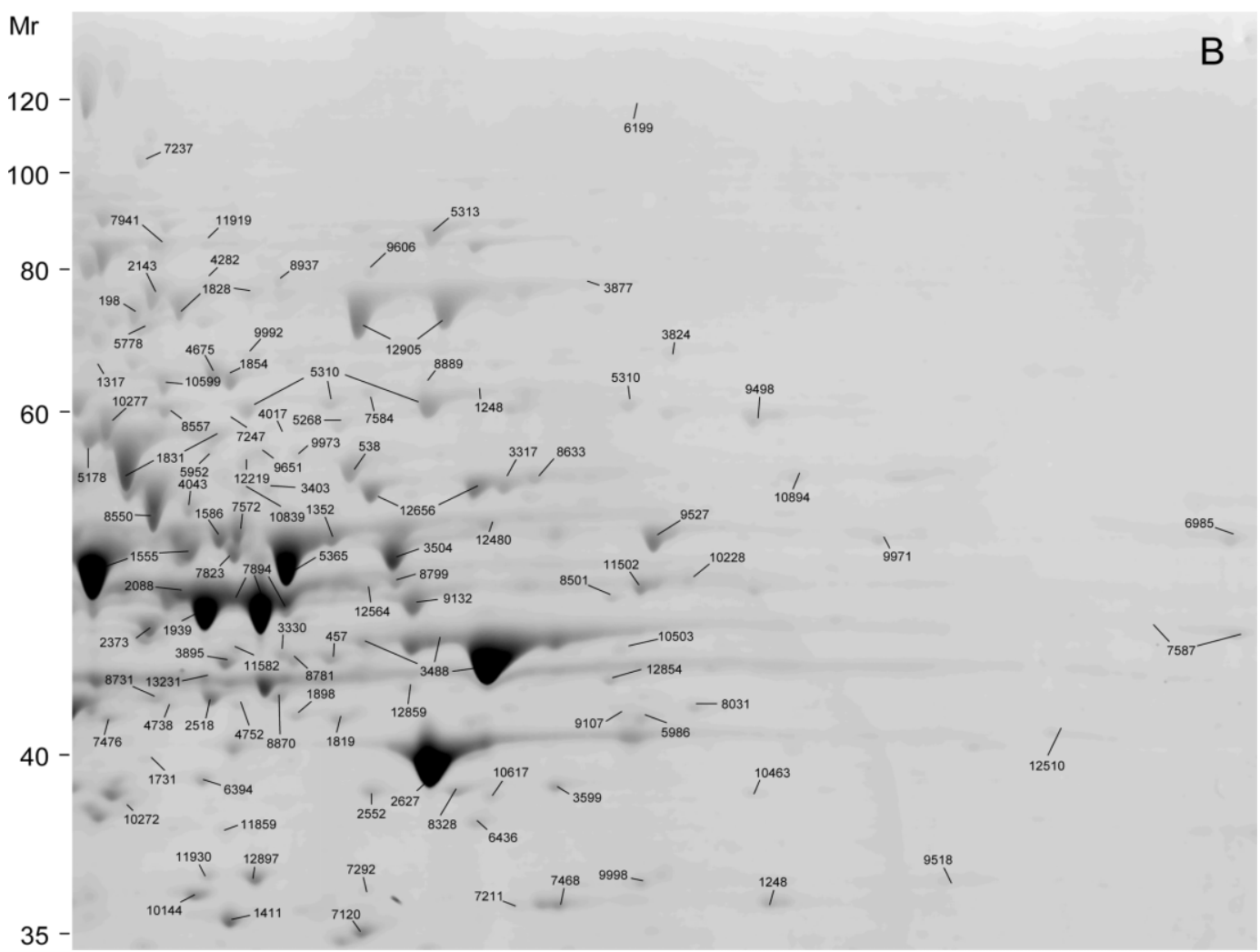

Figure 2. 

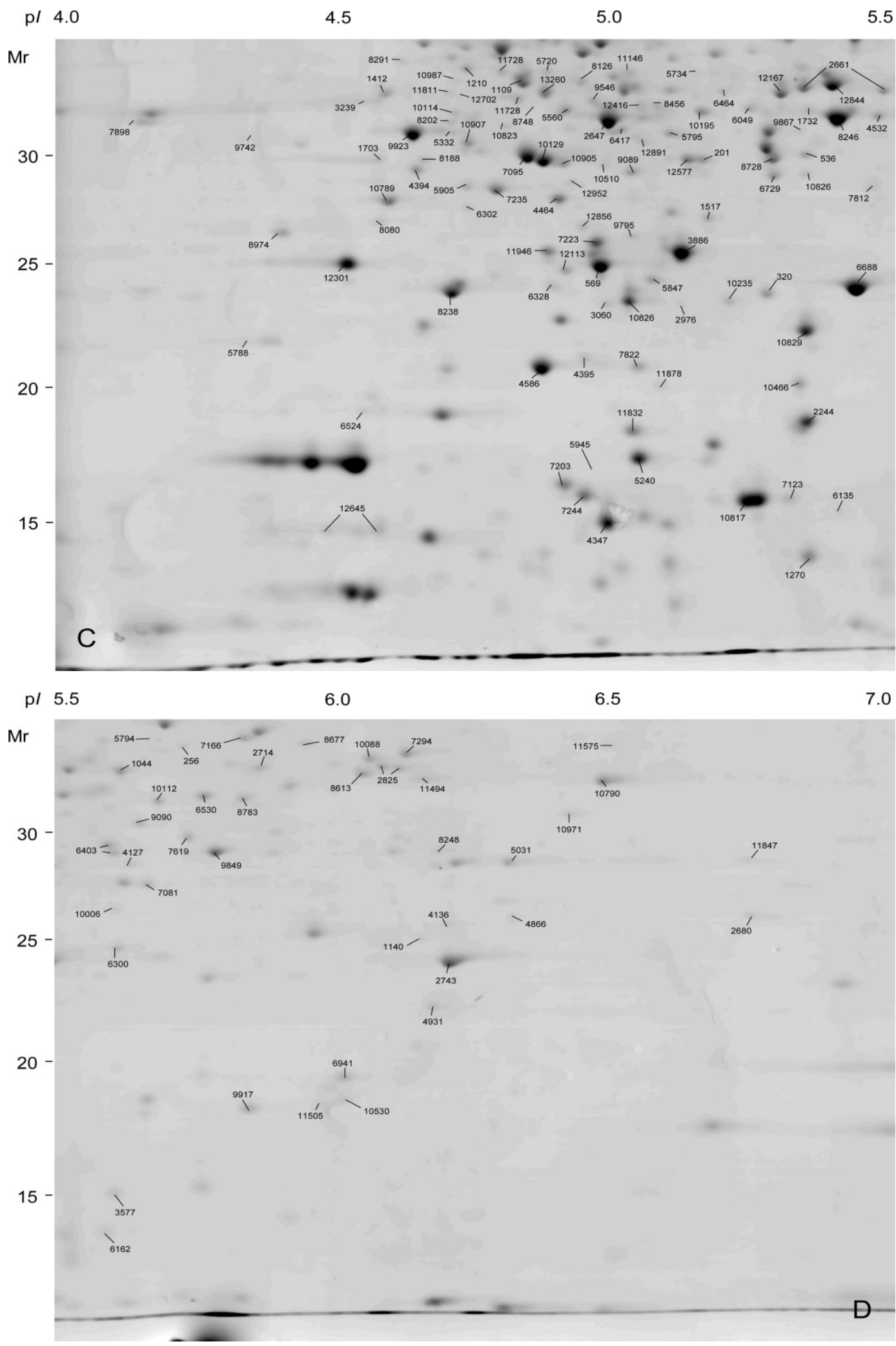

Figure 2. Annotated sections (A-D) of the master gel of soluble proteins of $R$. baltica grown with ribose. Assigned numbers represent genes. Table 2 lists the identified proteins according to functional classes and provides for each protein information on functional prediction, quality/reproducibility of identification, and prediction of signal peptides and expression level. 


\subsection{Proteins with functional assignment}

Functions could be assigned to the majority (366) of the identified proteins. These proteins were classified according to their predicted functions into nine categories (Table 1). The category "metabolism" was further divided into eight sub-categories (Table 2). The sub-category "sulfatases" was used, since the presence of 110 sulfatase-encoding genes was one of the major unexpected findings from the annotation of the $R$. baltica genome [26], 10 of which were identified on the gel.

The pattern of identified proteins displayed in Fig. 2 is typical of exponentially growing cells, with the most abundant proteins involved mainly in housekeeping functions, e.g., GAPDH (RB2627) of glycolysis, malate dehydrogenase (RB7652) of tricarboxic acid cycle, glutamate synthase (RB5653) of amino acid biosynthesis, protease (RB9402) of protein quality control and translation. The fact that several proteins existed as more than a single spot could point to thus far unknown post-translational modifications. In particular, proteins with high molecular weight formed chains with the same $M_{\mathrm{r}}$ but differing $\mathrm{p} I$.

Table 1. Distribution of identified proteins among functional groups

\begin{tabular}{lcc}
\hline Functional groups & $\begin{array}{l}\text { Number of } \\
\text { identified } \\
\text { proteins }\end{array}$ & $\begin{array}{l}\text { Share (\%) } \\
\text { among identi- } \\
\text { fied proteins }\end{array}$ \\
\hline Metabolism & 250 & 45 \\
$\begin{array}{l}\text { Genetic information } \\
\text { processing }\end{array}$ & 52 & 9 \\
Regulation and signal & 24 & 4 \\
$\quad$ transduction & 13 & 2 \\
$\begin{array}{l}\text { Stress response } \\
\text { Energy }\end{array}$ & 8 & 1 \\
$\begin{array}{l}\text { Transport } \\
\text { Conserved hypothetical } \\
\quad \text { proteins }\end{array}$ & 11 & 2 \\
Hypothetical proteins & 94 & 17 \\
Others & 98 & 18 \\
\hline
\end{tabular}

\subsection{Hypothetical and conserved hypothetical proteins}

About $18 \%$ of the identified proteins represent predicted hypothetical proteins that are apparently unique to $R$. baltica. Thus the present study for the first time provides experimental evidence that genes coding for hypothetical proteins are actually expressed under standard growth conditions and consequently have to be considered relevant for the physiology of R. baltica. Conserved hypothetical proteins constitute about the same percentage of identified proteins. In both cases no functions could be assigned. Nevertheless, the hy- pothetical proteins could be of particular interest with respect to the cell cycle and unusual morphological features of $R$. baltica, which may require the activity of thus far unknown proteins.

\subsection{Identification of unpredicted proteins}

Initial analysis of the $R$. baltica genome sequence with three different ORF prediction programs (Orpheus, Glimmer, and Critica) generated a non-redundant set of 13331 predicted ORFs. Manual removal of presumably overpredicted ORFs resulted in the published set of 7325 ORF (BX119912) [26]. Thus, the possibility exists that ORFs were initially not predicted or were erroneously removed during manual refinement. This possibility was compounded by the observation that several PMFs with abundant signals did not result in identification of a protein.

As a first attempt to identify proteins encoded by genes that were not present in the predicted ORF set, the PMF data were searched against an amino acid sequence database translated from a Maximal ORF Set (MOS); a highly redundant set consisting of 578949 sequence entries, designed to contain all possible genes and all possible reading lengths thereof. To reduce the number of false positive results, identifications for which the experimental and calculated molecular weight differed by $>30 \%$ were discarded. This database search retrieved four proteins with scores $>51$, which are listed in Table 3. All of the newly identified genes code for hypothetical proteins, which are surrounded by further hypothetical or conserved hypothetical proteins in the genomic context. For example, ORF 9191 from MOS was identified with a MASCOT score of 101 and sequence coverage of $62 \%$. The position of the corresponding spot on the 2-DE gel was used as a guide to suggest the ORF length by defining the probable start codon. The product of ORF 9191 is therefore predicted to have a molecular mass of $25 \mathrm{kDa}$. These results indicate that PMF is not necessarily restricted to identification in protein databases, but can also be used to refine ORF prediction. However, future analysis should include MS/MS to verify the identity of the additional proteins.

\subsection{Signal peptides and protein localization}

As observed with other described Planctomycetes, cells of $R$. baltica contain membrane-separated intracytoplasmic compartments [31]. The internal region is termed pirellulosome and contains the riboplasm with ribosome-like particles and the condensed nucleoid (Fig. 3). The region between the intracytoplasmic and cytoplasmic membranes contains the paryphoplasm that harbors some RNA but no ribosomelike particles. The finding that ribosome-like particles are confined to the riboplasm suggests that protein biosynthesis only takes place in this compartment. Due to the cellular compartmentalization in $R$. baltica an extensive protein translocation can be expected. 
Table 2. Predicted functions of proteins annotated in the master gel (see Fig. 2A-D) a)

\begin{tabular}{|c|c|c|c|c|c|}
\hline ORF & Putative Function & $\mathrm{sp}$ & $\mathrm{PHX}$ & Score & * \\
\hline & Metabolism (250 proteins) & & & & \\
\hline & $\underline{\text { C-compound and Carbohydra }}$ & cate & & & \\
\hline 201 & $\begin{array}{l}\text { Sugar phosphate isomerase/ } \\
\text { epimerase }\end{array}$ & & & 190 & 1 \\
\hline 307 & $\begin{array}{l}\text { NAD dependent malic } \\
\text { enzyme }\end{array}$ & & + & 201 & 2 \\
\hline 344 & Xanthan lyase & + & & 132 & \\
\hline 399 & $\begin{array}{l}\text { Glucose-6-phosphate } \\
\text { isomerase }\end{array}$ & & & 139 & 1 \\
\hline 548 & $\begin{array}{l}\text { 1,4-alpha-glucan branching } \\
\text { enzyme }\end{array}$ & & & 233 & 2 \\
\hline 856 & $\begin{array}{l}\text { L-Lactate/malate dehydro- } \\
\text { genase }\end{array}$ & + & & 131 & \\
\hline 1210 & $\begin{array}{l}\text { Hexulose-6-phosphate } \\
\text { isomerase }\end{array}$ & & + & 105 & 1 \\
\hline 1231 & $\begin{array}{l}\text { Dihydrolipoamide dehydro- } \\
\text { genase }\end{array}$ & & + & 135 & 2 \\
\hline 1358 & $\begin{array}{l}\text { ADP-glucose pyro- } \\
\text { phosphorylase }\end{array}$ & & & 198 & \\
\hline 1412 & Inositol monophosphatase & & & 124 & 1 \\
\hline 1593 & Isocitrate dehydrogenase & & & 192 & 2 \\
\hline 1988 & Glucose dehydrogenase & + & & 283 & \\
\hline 2114 & Aconitate hydratase & & + & 178 & 2 \\
\hline 2160 & Alpha-Amylase & & + & 229 & \\
\hline 2373 & $\begin{array}{l}\text { Formaldehyde dehydroge- } \\
\text { nase }\end{array}$ & & + & 213 & 2 \\
\hline 2403 & $\begin{array}{l}\text { D-mannonate oxidore- } \\
\text { ductase }\end{array}$ & & & 150 & \\
\hline 2518 & $\begin{array}{l}\text { GDP-mannose 4,6 dehy- } \\
\text { dratase }\end{array}$ & & + & 162 & 2 \\
\hline 2627 & $\begin{array}{l}\text { Glyceraldehyde 3-phosphate } \\
\text { dehydrogenase }\end{array}$ & & + & 230 & 2 \\
\hline 2638 & Glycogen branching enzyme & & & 133 & 1 \\
\hline 2658 & Xylose isomerase & & + & 196 & 2 \\
\hline 2817 & $\begin{array}{l}\text { 6-Phosphogluconate dehy- } \\
\text { drogenase }\end{array}$ & & + & 194 & 2 \\
\hline 3193 & Transaldolase & & + & 233 & 2 \\
\hline 3239 & D-tagatose 3-epimerase & & + & 54 & 1 \\
\hline 3265 & $\begin{array}{l}\text { Glucose-fructose oxidore- } \\
\text { ductase }\end{array}$ & & & 117 & \\
\hline 3423 & $\begin{array}{l}\text { Pyruvate dehydrogenase, E2 } \\
\text { component }\end{array}$ & & + & 144 & 2 \\
\hline 3424 & $\begin{array}{l}\text { Pyruvate dehydrogenase, E1 } \\
\text { component }\end{array}$ & & + & 288 & \\
\hline 3488 & Sorbitol dehydrogenase & & & 244 & \\
\hline 3499 & Ribokinase & & & 124 & \\
\hline 4131 & Alcohol dehydrogenase & & & 108 & 2 \\
\hline 4654 & $\begin{array}{l}\text { Sugar phosphate isomerase/ } \\
\text { epimerase }\end{array}$ & & + & 124 & 2 \\
\hline 5200 & Alpha-Amylase & & & 129 & \\
\hline 5243 & Endo-1,4-beta-xylanase B & & & 72 & 2 \\
\hline 5321 & $\begin{array}{l}\text { Myo-inositol catabolism } \\
\text { protein lolH }\end{array}$ & & & 99 & \\
\hline 5948 & Alcohol dehydrogenase & & & 157 & 2 \\
\hline 6061 & Phosphomannomutase & & & 310 & 2 \\
\hline
\end{tabular}

Table 2. Continued

\begin{tabular}{|c|c|c|c|c|c|}
\hline ORF & Putative Function & $\mathrm{sp}$ & PHX & Score & * \\
\hline 6254 & $\begin{array}{l}\text { Mannose-1-phosphate } \\
\text { guanylyltransferase }\end{array}$ & & & 80 & \\
\hline 6394 & $\begin{array}{l}\text { 2-Hydroxy acid dehydroge- } \\
\text { nase }\end{array}$ & & & 162 & 2 \\
\hline 6683 & Citrate synthase & & & 150 & 2 \\
\hline 6690 & $\begin{array}{l}\text { Fructose-1,6-bisphosphate } \\
\text { aldolase }\end{array}$ & & + & 130 & 2 \\
\hline 6729 & $\begin{array}{l}\text { Deoxyribose-phosphate } \\
\text { aldolase }\end{array}$ & & + & 55 & 1 \\
\hline 6759 & $\begin{array}{l}\text { Methenyltetrahydrome- } \\
\text { thanopterin cyclohy- } \\
\text { drolase }\end{array}$ & & & 60 & \\
\hline 6807 & $\begin{array}{l}\text { Sialic acid-specific } \\
\text { 9-O-acetylesterase }\end{array}$ & + & & 131 & \\
\hline 6841 & $\begin{array}{l}\text { UDP- } N \text {-Acetylglucosamine } \\
\text { pyrophosphorylase }\end{array}$ & & & 142 & 1 \\
\hline 6977 & $\begin{array}{l}\text { UDP-N-Acetylhexosamine } \\
\text { pyrophosphorylase }\end{array}$ & & & 158 & 2 \\
\hline 7095 & Triosephosphate isomerase & & + & 109 & 2 \\
\hline 7294 & Glucose 1-dehydrogenase & & & 159 & 1 \\
\hline 7572 & $\begin{array}{c}\text { 6-Phosphofructokinase, py- } \\
\text { rophosphate-dependent }\end{array}$ & & + & 105 & 1 \\
\hline 7652 & Malate dehydrogenase & & + & 138 & 2 \\
\hline 8073 & $\begin{array}{l}\text { Alpha-L-arabinofuranosi- } \\
\text { dase II }\end{array}$ & + & & 151 & 2 \\
\hline 8248 & $\begin{array}{l}\text { Carboxymethylenebutenol- } \\
\text { idase }\end{array}$ & & & 112 & \\
\hline 8541 & Endoglucanase & & + & 147 & 2 \\
\hline 8562 & Phosphoglycerate mutase & & & 82 & \\
\hline 8731 & $\begin{array}{l}\text { 2-keto-3-deoxygluconate } \\
\text { kinase }\end{array}$ & & + & 91 & 2 \\
\hline 8924 & $\begin{array}{l}\text { Phosphonopyruvate de- } \\
\text { carboxylase } 1\end{array}$ & & + & 131 & 2 \\
\hline 8941 & $\begin{array}{l}\text { Ketoglutarate semialdehyde } \\
\text { dehydrogenase }\end{array}$ & & & 67 & 2 \\
\hline 9089 & 6-Phosphogluconolactonase & & & 117 & 2 \\
\hline 9651 & $\begin{array}{l}\text { Sialic acidspecific 9-O-acetyl- } \\
\quad \text { esterase }\end{array}$ & & & 80 & \\
\hline 10002 & Glucose dehydrogenase & & + & 133 & 2 \\
\hline 10048 & $\begin{array}{l}\text { Sialic acidspecific } 9 \text {-O-acetyl } \\
\text { esterase }\end{array}$ & & + & 140 & \\
\hline 10092 & $\begin{array}{l}\text { Hydratase, aerobic aromate } \\
\text { catabolism }\end{array}$ & & & 74 & 2 \\
\hline 10124 & $\begin{array}{l}\text { Polyvinylalcohol } \\
\text { dehydrogenase }\end{array}$ & + & & 147 & \\
\hline 10127 & $\begin{array}{l}\text { PQQ-dependent glucose } \\
\text { dehydrogenase }\end{array}$ & + & & 89 & 2 \\
\hline 10144 & Endo-1,4-beta-xylanase B & + & & 121 & \\
\hline 10172 & Aldehyde dehydrogenase & & + & 218 & 2 \\
\hline 10277 & Pyruvate kinase & & & 138 & 2 \\
\hline 10500 & Phosphoglycerate kinase & & + & 142 & 2 \\
\hline 10554 & $\begin{array}{l}\text { Succinate dehydrogenase } \\
\text { subunit A }\end{array}$ & & + & 238 & 2 \\
\hline 10591 & PPi-Phosphofructokinase & & + & 164 & 2 \\
\hline 10617 & $\begin{array}{l}\text { Succinyl-CoA synthetase } \\
\text { beta subunit }\end{array}$ & & + & 99 & 2 \\
\hline
\end{tabular}


Table 2. Continued

\begin{tabular}{|c|c|c|c|c|c|}
\hline ORF & Putative Function & $\mathrm{sp}$ & PHX & Score & * \\
\hline 10619 & $\begin{array}{l}\text { Succinyl-CoA synthetase } \\
\text { alpha subunit }\end{array}$ & & + & 103 & 2 \\
\hline 10817 & $\begin{array}{l}\text { Ribose 5-phosphate epime- } \\
\quad \text { rase }\end{array}$ & & + & 81 & \\
\hline 12361 & $\begin{array}{l}\text { Ribokinase family sugar } \\
\text { kinase }\end{array}$ & & & 175 & 2 \\
\hline 12381 & Enolase & & + & 212 & 2 \\
\hline 12740 & Gluconolactonase precursor & & & 101 & \\
\hline 12921 & Transketolase & & + & 151 & 2 \\
\hline 13260 & Alcohol dehydrogenase & & & 73 & \\
\hline 13264 & $\begin{array}{l}\text { Acetyl-coenzyme A syn- } \\
\text { thetase }\end{array}$ & & & 220 & 2 \\
\hline
\end{tabular}

$\underline{\text { Amino Acids and Proteins }}$

\begin{tabular}{|c|c|c|c|}
\hline 1225 & Dipeptidyl peptidase IV & + & 158 \\
\hline 1317 & 2-Isopropylmalate synthase & & 147 \\
\hline 1359 & Serine protease & & 156 \\
\hline 1411 & $\begin{array}{l}\text { Dihydrodipicolinate } \\
\text { synthase }\end{array}$ & + & 178 \\
\hline 1732 & Beta-Alanine synthetase & + & 73 \\
\hline 1898 & Dehydroquinate synthase & & 101 \\
\hline 261 & $\begin{array}{l}\text { Carboxypeptidase-related } \\
\text { protein }\end{array}$ & + & 187 \\
\hline 2278 & $\begin{array}{l}\text { 3-Phosphoshikimate } \\
\text { 1-carboxyvinyltransferase }\end{array}$ & & 131 \\
\hline 2552 & $\begin{array}{l}\text { N-Acetyl-gamma-glutamyl- } \\
\text { phosphate reductase }\end{array}$ & + & 172 \\
\hline 2661 & $\begin{array}{l}\text { UDP- } N \text {-Acetyl- } \\
\text { enolpyruvoylglucosamine } \\
\text { reductase }\end{array}$ & & 63 \\
\hline 2746 & $\begin{array}{l}\text { Dihydrodipicolinate } \\
\text { synthase }\end{array}$ & & 100 \\
\hline 3824 & L-Aspartate oxidase & & 176 \\
\hline 3842 & Dipeptidyl peptidase IV & + & 220 \\
\hline 4282 & Matrix metalloproteinase-11 & & 71 \\
\hline 4394 & Proteinase & + & 65 \\
\hline 4928 & Aminopeptidase & & 244 \\
\hline 5444 & $\begin{array}{l}\text { S-Adenosylmethionine syn- } \\
\text { thetase }\end{array}$ & + & 234 \\
\hline 5560 & $\begin{array}{l}\text { Tryptophan synthase alpha } \\
\text { chain }\end{array}$ & & 126 \\
\hline 5653 & $\begin{array}{l}\text { NADH-Glutamate synthase } \\
\text { small chain }\end{array}$ & + & 134 \\
\hline 5720 & Amidohydrolase & & 74 \\
\hline 5986 & $\begin{array}{l}\text { Ornithine carbamoyltrans- } \\
\text { ferase }\end{array}$ & & 151 \\
\hline 6248 & $\begin{array}{l}\text { Phosphoglycerate dehydro- } \\
\text { genase }\end{array}$ & & 149 \\
\hline 6285 & Adenosylhomocysteinase & + & 152 \\
\hline 6300 & Glutamine amido-transferase & & 119 \\
\hline 6821 & Aspartate aminotransferase & + & 88 \\
\hline 6932 & Cysteine synthase & & 126 \\
\hline 7359 & $\begin{array}{l}\text { Gamma-glutamyl phosphate } \\
\text { reductase }\end{array}$ & + & 99 \\
\hline 737 & Aminopeptidase $T$ & & 115 \\
\hline
\end{tabular}

Table 2. Continued

\begin{tabular}{|c|c|c|c|c|c|}
\hline ORF & Putative Function & $\mathrm{sp}$ & $\mathrm{PHX}$ & Score & * \\
\hline 7584 & $\begin{array}{l}\text { Glycine dehydrogenase (de- } \\
\text { carboxylating) subunit } 2\end{array}$ & & & 154 & \\
\hline 7587 & $\begin{array}{l}\text { Aminotransferase-glycine } \\
\text { cleavage system T protein }\end{array}$ & & & 238 & \\
\hline 7590 & Proteinase & & & 174 & 2 \\
\hline 7823 & Transaminase & & & 123 & \\
\hline 7941 & $\begin{array}{l}\text { cys } \mathrm{N} / \text { cys } \mathrm{C} \text { bifunctional } \\
\text { enzyme }\end{array}$ & & & 245 & 2 \\
\hline 8080 & $\begin{array}{l}\text { Phosphoribosylformimino-5- } \\
\text { aminoimidazole carbox- } \\
\text { amide botide isomerase, } \\
\text { biosynthesis of histidine }\end{array}$ & & & 127 & \\
\hline 8126 & $\begin{array}{l}\text { Branched-chain amino acid } \\
\text { aminotransferase }\end{array}$ & & + & 111 & 2 \\
\hline 8219 & Aspartate aminotransferase & & & 135 & 2 \\
\hline 8262 & Proline dehydrogenase & & & 147 & \\
\hline 8293 & Argininosuccinate synthase & & + & 144 & 2 \\
\hline 8633 & $\begin{array}{l}\text { Acetylornithine aminotrans- } \\
\text { ferase }\end{array}$ & & + & 119 & \\
\hline 8926 & Aspartokinase & & + & 93 & \\
\hline 9029 & Metalloproteinase & & & 200 & 2 \\
\hline 9107 & Chorismate mutase & & & 150 & \\
\hline 9402 & Protease & & + & 170 & 1 \\
\hline 9674 & X-Pro dipeptidyl-peptidase & + & & 134 & 1 \\
\hline 9795 & $\begin{array}{l}\text { Aspartate-semialdehyde } \\
\text { dehydrogenase }\end{array}$ & & + & 117 & 2 \\
\hline 9857 & $\begin{array}{l}\text { 5-Methyltetrahydrofolate- } \\
\text { homocysteine methyl- } \\
\text { transferase }\end{array}$ & & & 117 & \\
\hline 9869 & $\begin{array}{l}\text { Acetohydroxy acid iso- } \\
\text { meroreductase }\end{array}$ & & + & 170 & 2 \\
\hline 10112 & $\begin{array}{l}\text { Imidazole glycerol phosphate } \\
\text { synthase subunit hisF }\end{array}$ & & & 221 & 2 \\
\hline 10114 & $\begin{array}{l}\text { Indole-3-glycerol phosphate } \\
\text { synthase }\end{array}$ & & + & 161 & \\
\hline 10180 & Peptidase & & + & 173 & 2 \\
\hline 10272 & Pteridine reductase & & & 136 & 1 \\
\hline 10287 & Dihydropicolinate synthase & & + & 166 & 2 \\
\hline 10586 & Aminopeptidase & & & 165 & 1 \\
\hline 10826 & $\begin{array}{l}\text { ATP-dependent clp protease } \\
\text { proteolytic subunit }\end{array}$ & & & 120 & 2 \\
\hline 10829 & $\begin{array}{l}\text { ATP-dependent clp protease } \\
\text { proteolytic subunit }\end{array}$ & & + & 88 & 1 \\
\hline 10894 & $\begin{array}{l}\text { Threonine synthase } \\
\text { precursor }\end{array}$ & & + & 109 & 2 \\
\hline 11847 & $\begin{array}{l}\text { Methionine sulfoxide } \\
\text { reductase }\end{array}$ & + & & 81 & \\
\hline 11878 & $\begin{array}{l}\text { Methionine sulfoxide } \\
\text { reductase }\end{array}$ & & & 56 & \\
\hline 11879 & Periplasmic serine proteinase & & + & 91 & \\
\hline 11919 & Dihydroxy acid dehydratase & & & 59 & \\
\hline 11959 & $\begin{array}{l}\text { Dihydrodipicolinate } \\
\text { reductase }\end{array}$ & & & 114 & 2 \\
\hline 12087 & Dihydroxy acid dehydratase & & + & 94 & 2 \\
\hline 12107 & Cytosol aminopeptidase & & + & 165 & 2 \\
\hline
\end{tabular}


Table 2. Continued

\begin{tabular}{|c|c|c|c|c|c|}
\hline ORF & Putative Function & sp & PHX & Score & * \\
\hline 12113 & $\begin{array}{l}\text { Carbamoyl-phosphate syn- } \\
\text { thase large chain }\end{array}$ & & + & 177 & 2 \\
\hline 12133 & $\begin{array}{l}\text { Succinyl-diaminopimelate } \\
\text { desuccinylase }\end{array}$ & & + & 178 & 1 \\
\hline 12148 & $\begin{array}{l}\text { Periplasmic tail-specific } \\
\text { proteinase }\end{array}$ & + & + & 287 & 2 \\
\hline 12337 & Prolyl endopeptidase & + & + & 240 & 2 \\
\hline 12510 & $\begin{array}{l}\text { Phospho-2-dehydro-3- } \\
\text { deoxyheptonate aldolase }\end{array}$ & & & 143 & \\
\hline 12597 & $\begin{array}{l}\text { 3-Isopropylmalate dehydro- } \\
\text { genase }\end{array}$ & & & 131 & \\
\hline 12656 & $\begin{array}{l}\text { 3-Isopropylmalate dehy- } \\
\text { dratase large subunit }\end{array}$ & & & 226 & 2 \\
\hline \multirow[t]{2}{*}{12905} & $\begin{array}{l}\text { Acetolactate synthase III } \\
\text { precursor }\end{array}$ & & + & 172 & 2 \\
\hline & $\underline{\text { Nucleotides }}$ & & & & \\
\hline 1964 & $\begin{array}{l}\text { DNA-directed RNA poly- } \\
\text { merase alpha chain }\end{array}$ & & + & 191 & 2 \\
\hline 256 & $\begin{array}{l}\text { Formyltetrahydrofolate } \\
\text { deformylase }\end{array}$ & & & 145 & \\
\hline 1386 & Nucleoside hydrolase & + & & 128 & \\
\hline 1784 & $\begin{array}{l}\text { UDP-glucose 6-dehydro- } \\
\text { genase }\end{array}$ & & & 195 & 2 \\
\hline 1819 & UDP-glucose 4-epimerase & & & 176 & 2 \\
\hline 3751 & UDP-glucose 4-epimerase & & & 146 & 2 \\
\hline 4043 & $\begin{array}{l}\text { Glucose-1-phosphate thymi- } \\
\text { dylyltransferase }\end{array}$ & & & 89 & \\
\hline 4752 & $\begin{array}{l}\text { Dihydroorotate dehydro- } \\
\text { genase }\end{array}$ & & & 101 & \\
\hline 5395 & $\begin{array}{l}\text { Phosphoribosylformyl- } \\
\text { glycinamidine } \\
\text { synthase II }\end{array}$ & & + & 367 & 2 \\
\hline 5603 & $\begin{array}{l}\text { ATP phosphoribosyltrans- } \\
\text { ferase }\end{array}$ & & & 189 & 2 \\
\hline 5695 & Beta-alanine synthetase & & & 173 & 1 \\
\hline 5847 & $\begin{array}{l}\text { Adenine phosphoribosyl- } \\
\text { transferase }\end{array}$ & & & 92 & 2 \\
\hline 6135 & $\begin{array}{l}\text { Phosphoribosylamino- } \\
\text { imidazole carboxylase } \\
\text { catalytic subunit }\end{array}$ & & & 67 & \\
\hline 6302 & ADP-ribose pyrophosphatase & & & 79 & \\
\hline 6328 & Adenylyl cyclase & & & 107 & \\
\hline 6524 & $\begin{array}{l}\text { Hypoxanthine-guanine phos- } \\
\text { phoribosyltransferase }\end{array}$ & & & 79 & \\
\hline 6616 & $\begin{array}{l}\text { Phosphoribosylamine-gly- } \\
\text { cine ligase }\end{array}$ & & + & 99 & 1 \\
\hline 7468 & $\begin{array}{l}\text { Methylentetrahydrofolate } \\
\text { cyclohydrolase }\end{array}$ & & & 59 & \\
\hline 8374 & GMP synthase & & + & 265 & 2 \\
\hline 8613 & $\begin{array}{l}\text { Phosphoribosylform- } \\
\text { ylglycinamidine synthase I }\end{array}$ & & & 133 & 2 \\
\hline 8748 & $\begin{array}{l}\text { Dihydroorotate dehydro- } \\
\text { genase }\end{array}$ & & + & 65 & \\
\hline
\end{tabular}

Table 2. Continued

\begin{tabular}{|c|c|c|c|c|c|}
\hline ORF & Putative Function & $\mathrm{sp}$ & $\mathrm{PHX}$ & Score & * \\
\hline 10113 & $\begin{array}{l}\text { Bifunctional purine biosyn- } \\
\text { thesis protein purH }\end{array}$ & & + & 224 & 2 \\
\hline 10192 & Dihydroorotase & + & + & 96 & 2 \\
\hline 10510 & Cytidylate kinase & & + & 89 & \\
\hline 11832 & $\begin{array}{l}\text { Nucleoside diphosphate } \\
\text { kinase }\end{array}$ & & + & 71 & 2 \\
\hline 12745 & $\begin{array}{l}\text { Phosphoribosylformyl- } \\
\text { glycinamidine cyclo-ligase }\end{array}$ & & & 109 & 2 \\
\hline
\end{tabular}

Lipids, Fatty Acids and Isoprenoids protein transacylase

320 3-Oxoacyl-(acyl-carrier-pro- $\quad 173 \quad 2$ tein) synthase

1586 3-Oxoacyl-(acyl-carrier-pro- $\quad 104 \quad 2$ tein) synthase II

1839 Thiamine biosynthesis lipo- $\quad 136 \quad 2$ protein apbE

2144 Geranylgeranyl pyrophosphate synthetase precursor

2579 Ethanolamine utilization pro- $\quad+\quad 67$ tein EutE

2825 Glycerophosphodiester 113 phosphodiesterase

4527 3-Oxoacyl-(acyl-carrier-pro- $\quad+\quad 177 \quad 1$ tein) synthase

6272 3-Oxoacyl-(acyl-carrier-pro- 97 tein) synthase

6464 Sulfolipid biosynthesis pro- 85 tein

7171 3-Oxoacyl-(acyl-carrier-pro- $\quad+\quad 2192$ tein) synthase

7812 Enoyl-CoA hydratase/isom- 95 erase

8125 Trans-2-enoyl-(acyl-carrier- $\quad+\quad 752$ protein) reductase

8550 Biotin carboxylase

10466 Probable betahydroxyacylACP dehydratase

10790 Enoyl-(acyl-carrier-protein) _ + $\quad 127 \quad 2$ reductase (NADH)

12812 3-Oxoacyl-(acyl-carrier-pro- $\quad 60$ tein) synthase III

Vitamins, Cofactors and Prosthetic Groups

$\begin{array}{llrr}24 & \text { L-sorbosone dehydrogenase } & 197 & 2 \\ 309 & \begin{array}{l}\text { Magnesium protoporphyrin } \\ \text { chelatase }\end{array} & 95 & 2 \\ 536 & \begin{array}{l}\text { Pyridoxal phosphate biosyn- } \\ \text { thetic protein }\end{array} & 128 & 1 \\ 2143 & \begin{array}{l}\text { 1-Deoxy-D-xylulose 5-phos- } \\ \text { phate synthase }\end{array} & 226 & \\ & & \end{array}$


Table 2. Continued

\begin{tabular}{|c|c|c|c|c|c|}
\hline ORF & Putative Function & $\mathrm{sp}$ & $\mathrm{PHX}$ & Score & * \\
\hline 6809 & $\begin{array}{l}\text { Thiamine-monophosphate } \\
\text { kinase }\end{array}$ & & & 69 & 1 \\
\hline 6831 & $\begin{array}{l}\text { Glutamate-1-semialdehyde } \\
\text { 2,1-aminomutase }\end{array}$ & & & 89 & 1 \\
\hline 6964 & $\begin{array}{l}\text { L-sorbosone dehydro- } \\
\text { genase }\end{array}$ & + & & 123 & \\
\hline 9090 & $\begin{array}{l}\text { 3-Methyl-2-oxobutanoate } \\
\text { hydroxymethyltransferase }\end{array}$ & & & 64 & \\
\hline 10006 & Pyridoxamine oxidase & & & 71 & \\
\hline 11582 & Cysteine desulfurase & & & 86 & 1 \\
\hline \multirow[t]{2}{*}{12480} & $\begin{array}{l}\text { Riboflavin biosynthesis } \\
\text { protein RibA }\end{array}$ & & + & 91 & \\
\hline & $\underline{\text { Sulfatases }}$ & & & & \\
\hline 198 & $\begin{array}{l}\mathrm{N} \text {-acetylgalactosamine- } \\
\text { 4-sulfatase precursor }\end{array}$ & + & & 129 & \\
\hline 1610 & Arylsulfatase & + & & 100 & \\
\hline 2367 & Sulfatase & + & + & 121 & \\
\hline 3403 & $\begin{array}{l}\mathrm{N} \text {-acetylgalactosamine } \\
6 \text {-sulfatase }\end{array}$ & + & & 65 & \\
\hline 3877 & Arylsulfate sulphohydrolase & + & & 137 & \\
\hline 4017 & Sulfatase & & & 114 & \\
\hline 7481 & Arylsulphatase A & + & + & 162 & \\
\hline 9498 & Arylsulfatase & + & + & 139 & 2 \\
\hline 10599 & Sulfatase 1 precursor & + & & 161 & \\
\hline 11502 & Alkylsulfatase & + & & 60 & 2 \\
\hline & $\underline{\text { Inorganic Compounds }}$ & & & & \\
\hline 5869 & $\begin{array}{l}\text { Bacterioferritin comigratory } \\
\text { protein }\end{array}$ & & & 79 & \\
\hline 6049 & Adenylylsulfate kinase & & & 110 & \\
\hline 7247 & Glutamine synthetase II & & + & 136 & 2 \\
\hline 7465 & Sulfite reductase & & + & 65 & \\
\hline \multirow[t]{2}{*}{11670} & $\begin{array}{l}\text { Ferric enterobactin esterase- } \\
\text { related protein }\end{array}$ & & & 117 & \\
\hline & Others & & & & \\
\hline 203 & Oxidoreductase & & & 154 & 2 \\
\hline 1555 & $\begin{array}{l}\text { NADH-dependent dehydro- } \\
\text { genase }\end{array}$ & + & + & 154 & 2 \\
\hline 1608 & Esterase & + & & 125 & 2 \\
\hline 1939 & Oxidoreductase & & + & 212 & \\
\hline 2242 & Oxidoreductase & & + & 164 & 1 \\
\hline 3317 & $\begin{array}{l}\text { NADH-dependent dehydro- } \\
\text { genase }\end{array}$ & + & & 108 & \\
\hline 3330 & Dehydrogenase & & + & 104 & 1 \\
\hline 3405 & Hydrolase & + & & 275 & 2 \\
\hline 4404 & Oxidoreductase & & & 124 & 2 \\
\hline 4432 & Oxidoreductase & + & & 67 & 1 \\
\hline 5332 & Phosphoesterase & & & 53 & \\
\hline 5365 & $\begin{array}{l}\text { NADH-dependent dehydro- } \\
\text { genase }\end{array}$ & + & + & 165 & 2 \\
\hline 6199 & Dehydrogenase & + & + & 94 & 2 \\
\hline 6985 & $\begin{array}{l}\text { NADH-dependent dehydro- } \\
\text { genase }\end{array}$ & & + & 86 & \\
\hline
\end{tabular}

Table 2. Continued

\begin{tabular}{|c|c|c|c|c|c|}
\hline ORF & Putative Function & $\mathrm{sp}$ & $\mathrm{PHX}$ & Score & * \\
\hline 7081 & Oxidoreductase & & & 71 & \\
\hline 7482 & CDP-tyvelose epimerase & & + & 183 & 2 \\
\hline 7548 & $\begin{array}{l}\text { Syringomycin biosynthesis } \\
\text { enzyme } 2\end{array}$ & & & 133 & 2 \\
\hline 8679 & Oxidoreductase & & & 121 & \\
\hline 8728 & Oxidoreductase & & + & 119 & 2 \\
\hline 8781 & $\begin{array}{l}\text { NADH-dependent oxidore- } \\
\text { ductase }\end{array}$ & & + & 182 & \\
\hline 8799 & $\begin{array}{l}\text { NADH-dependent dehydro- } \\
\text { genase }\end{array}$ & & & 159 & 2 \\
\hline 8937 & $\begin{array}{l}\text { NADH-dependent dehydro- } \\
\text { genase }\end{array}$ & & & 94 & \\
\hline 9168 & Nucleotide sugar epimerase & & & 68 & 2 \\
\hline 9584 & Oxidoreductase & & & 74 & \\
\hline 9586 & Oxidoreductase & & & 116 & \\
\hline 9971 & $\begin{array}{l}\text { NADH-dependent dehydro- } \\
\text { genase }\end{array}$ & + & + & 116 & 1 \\
\hline 10503 & $\begin{array}{l}\text { NADH-dependent oxidore- } \\
\text { ductase }\end{array}$ & & + & 142 & 2 \\
\hline 10652 & $C$-methyltransferase & & & 103 & 1 \\
\hline 10967 & Oxidoreductase & & + & 91 & \\
\hline 10971 & Dehydrogenase & & & 96 & 1 \\
\hline 11146 & Hydrolase & & & 99 & \\
\hline 11859 & Hydrolase & & & 167 & \\
\hline 12019 & Oxidoreductase & & & 74 & 1 \\
\hline 12564 & $\begin{array}{l}\text { NADH-dependent dehydro- } \\
\text { genase }\end{array}$ & + & & 139 & 1 \\
\hline
\end{tabular}

\section{Stress Response (13 proteins)}

\begin{tabular}{|c|c|c|c|c|c|}
\hline 390 & Alkylhalidase, dehalogenase & & & 167 & \\
\hline 2244 & Glutathione peroxidase & + & + & 75 & \\
\hline 2799 & General stress protein 69 & & & 107 & 2 \\
\hline 4586 & Thiol peroxidase & & + & 92 & 2 \\
\hline 6384 & Thioredoxin related protein & + & & 116 & \\
\hline 6688 & $\begin{array}{l}\text { Superoxide dismutase, } \mathrm{Mn} \\
\text { family }\end{array}$ & & + & 86 & 2 \\
\hline 7223 & Thioredoxin reductase & & + & 76 & 2 \\
\hline 8238 & Peroxiredoxin 2 & & + & 72 & 2 \\
\hline 8674 & Thioredoxin & + & + & 145 & \\
\hline 8870 & Multidrug resistance protein & & + & 127 & 1 \\
\hline 10727 & $\begin{array}{l}\text { Manganese-containing cata- } \\
\text { lase }\end{array}$ & & & 73 & 2 \\
\hline 11150 & Xenobiotic reductase B & & & 114 & 1 \\
\hline \multirow[t]{2}{*}{12541} & Thioredoxin & + & & 214 & 2 \\
\hline & Transport (11 proteins) & & & & \\
\hline 1248 & $\begin{array}{l}\text { ATPase component; multi- } \\
\text { drug transport system }\end{array}$ & & + & 117 & 2 \\
\hline 1517 & $\begin{array}{l}\text { ATP-binding protein, lipo- } \\
\text { protein releasing system }\end{array}$ & & & 75 & \\
\hline 4866 & $\begin{array}{l}\text { ATP-binding protein, lipo- } \\
\text { protein releasing system }\end{array}$ & & & 69 & \\
\hline 5795 & $\begin{array}{l}\text { PTS system, fructose-specific } \\
\text { IIABC component }\end{array}$ & & & 114 & 2 \\
\hline 6236 & $\begin{array}{l}\text { ATP-binding protein, ABC- } \\
\text { transport system }\end{array}$ & & & 147 & 2 \\
\hline
\end{tabular}


Table 2. Continued

\begin{tabular}{|c|c|c|c|c|c|}
\hline ORF & Putative Function & $\mathrm{sp}$ & PHX & Score & * \\
\hline 7166 & $\begin{array}{l}\text { ATP-binding protein, ABC- } \\
\text { transport system }\end{array}$ & & & 89 & 1 \\
\hline 7211 & $\begin{array}{l}\text { ATP-binding protein, phos- } \\
\text { phate transport }\end{array}$ & & & 186 & \\
\hline 9998 & $\begin{array}{l}\text { ATP-binding protein, ABC- } \\
\text { transport system }\end{array}$ & & + & 67 & \\
\hline 10709 & $\begin{array}{l}\text { Periplasmic dipeptide trans- } \\
\text { port protein precursor }\end{array}$ & + & & 203 & \\
\hline 11930 & $\begin{array}{l}\text { ATP-binding protein, ABC- } \\
\text { transport system }\end{array}$ & & & 158 & 2 \\
\hline 12859 & $\begin{array}{l}\text { ATP-binding protein, oli- } \\
\text { gopeptide transport }\end{array}$ & & & 124 & \\
\hline
\end{tabular}

\section{Genetic Information Processing (52 proteins)}

Competence-damage in931 ducible protein CinA

1270 Translation initiation inhibitor

1485 DNA polymerase beta family

1964 DNA-directed RNA polymerase alpha chain

254330 S ribosomal protein S1

3446 Peptidyl-prolyl cis-trans isomerase cyp2

3886 Ribosome recycling factor

4143 Glutamyl-tRNA amidotransferase subunit $A$

4395 Macrophage infectivity potentiator (map) protein

4675 Cysteinyl-tRNA synthetase

5178 Prolyl-tRNA synthetase

5414 DNA-directed RNA polymerase beta chain

5434 Elongation factor $\mathrm{G}$

5681 Trigger factor

5697 Thiol-disulfide interchange protein

5747 Arginyl-tRNA synthetase

5754 DnaK

5778 Alkaline phosphatase

5804 Polyribonucleotide nucleotidyltransferase

5813 Alkaline phosphatase D + 105

6123 Protein disulfide-isomerase + 201

6436 Tryptophan-tRNA synthetase

7112 Phenylalanyl-tRNA synthetase beta chain

7114 Phenylalanyl-tRNA synthetase alpha chain

7237 DNA mismatch repair protein MUTS

\begin{tabular}{|c|c|}
\hline- & 65 \\
\hline & 193 \\
\hline+ & 191 \\
\hline+ & 159 \\
\hline & 100 \\
\hline & 106 \\
\hline & 127 \\
\hline+ & 83 \\
\hline & 108 \\
\hline & 218 \\
\hline+ & 53 \\
\hline+ & 126 \\
\hline+ & 142 \\
\hline & 52 \\
\hline & 205 \\
\hline & 97 \\
\hline & 234 \\
\hline+ & 56 \\
\hline & 105 \\
\hline+ & 201 \\
\hline & 79 \\
\hline & 131 \\
\hline & 129 \\
\hline+ & 98 \\
\hline & 61 \\
\hline+ & 253 \\
\hline+ & 187 \\
\hline+ & 249 \\
\hline+ & 151 \\
\hline
\end{tabular}

Peptidylprolyl cis-trans isomerase

7821 Elongation factor $\mathrm{G}$

7894 Elongation factor Tu

8253 Aspartyl-tRNA synthetase

8328 CMP-binding protein
Table 2. Continued

\begin{tabular}{|c|c|c|c|c|c|}
\hline ORF & Putative Function & $\mathrm{sp}$ & PHX & Score & $*$ \\
\hline 8649 & $\begin{array}{l}\text { Peptidylprolyl cis-trans } \\
\text { isomerase }\end{array}$ & + & + & 100 & \\
\hline 8889 & $\begin{array}{l}\text { Alkaline phosphatase D } \\
\text { precursor }\end{array}$ & + & & 132 & \\
\hline 8919 & Leucyl-tRNA synthetase & & + & 172 & \\
\hline 8966 & $60 \mathrm{kDa}$ chaperonin & & + & 198 & 2 \\
\hline 8970 & $60 \mathrm{kDa}$ chaperonin & & + & 148 & 2 \\
\hline 8974 & GrpE chaperone & & + & 57 & \\
\hline 9103 & $\begin{array}{l}\text { ATPases with chaperone ac- } \\
\text { tivity, ATP-binding subunit }\end{array}$ & & & 155 & 1 \\
\hline 9105 & DnaK & & + & 168 & \\
\hline 9917 & Single-strand binding protein & & & 110 & \\
\hline 9923 & 50 S ribosomal protein L25 & & + & 117 & 2 \\
\hline 9927 & $\begin{array}{l}\text { ATP-dependent Clp protease } \\
\text { ATP-binding subunit }\end{array}$ & & + & 89 & \\
\hline 10108 & $\begin{array}{l}\text { DNA polymerase III, beta } \\
\text { chain }\end{array}$ & & & 212 & 1 \\
\hline 10129 & $\begin{array}{l}\text { Macrophage infectivity } \\
\text { potentiator (map) } \\
\text { protein }\end{array}$ & + & + & 76 & \\
\hline 10629 & GroEL & & + & 172 & 2 \\
\hline 10640 & Elongation factor Ts & & + & 211 & 2 \\
\hline 10852 & $\begin{array}{l}\text { Glutamyl-tRNA amidotrans- } \\
\text { ferase subunit B }\end{array}$ & & + & 114 & 2 \\
\hline 10883 & Lysyl-tRNA synthetase & + & + & 153 & 2 \\
\hline 12577 & Elongation factor $\mathrm{P}$ & & & 90 & \\
\hline 12626 & $\begin{array}{l}\text { DNA-directed RNA poly- } \\
\text { merase alpha chain }\end{array}$ & & + & 287 & 2 \\
\hline 12799 & DNA polymerase I & & + & 205 & \\
\hline 12854 & $\begin{array}{l}\text { Methionyl-tRNA formyltrans- } \\
\text { ferase }\end{array}$ & & & 159 & 2 \\
\hline 12856 & Peptide deformylase & & + & 121 & 1 \\
\hline
\end{tabular}

Regulation and Signal Transduction (24)

983 Phosphoprotein kinase $\quad+\quad 189$

1140 Response regulator 101

1321 Transcription repressor 93

1483 Sensor histidine kinase/re- 58 sponse regulator

2743 Nitrate/nitrite regulatory $\quad+\quad 159 \quad 2$ protein NarP

4081 Regulatory protein $\quad 146 \quad 2$

4136 Regulatory components of +53 sensory transduction system

4487 Nitrogen assimilation regula- 168 tory protein

5905 Phosphoprotein phos- 60 phatase

6403 Response regulator 119

6486 Phosphoprotein kinase $+\quad 165$

6491 RNA polymerase subunit 134 sigma54

6603 MoxR-related protein $\quad+\quad 164 \quad 1$

7123 Response regulator

7541 Phosphoprotein kinase 
Table 2. Continued

\begin{tabular}{|c|c|c|c|c|c|}
\hline ORF & Putative Function & $\mathrm{sp}$ & $\mathrm{PHX}$ & Score & * \\
\hline 7898 & $\begin{array}{l}\text { Transcription antiterminator } \\
\text { NusG }\end{array}$ & & + & 109 & 1 \\
\hline 8173 & MoxR-related protein & & & 113 & \\
\hline 9108 & MoxR-related protein & & & 109 & 2 \\
\hline 9110 & Phosphoprotein kinase & & & 162 & 2 \\
\hline 10491 & $\begin{array}{l}\text { Two-component system re- } \\
\text { gulatory protein }\end{array}$ & & & 71 & \\
\hline 10517 & $\begin{array}{l}\text { Methanol dehydrogenase } \\
\text { regulation homolog YeaC }\end{array}$ & & & 134 & 1 \\
\hline 10839 & Phosphoprotein kinase & & & 101 & \\
\hline 11660 & Phosphoprotein kinase & + & & 218 & \\
\hline \multirow[t]{2}{*}{12952} & $\begin{array}{l}\text { Two-component system, } \\
\text { regulatory protein }\end{array}$ & & & 69 & \\
\hline & Energy (8 proteins) & & & & \\
\hline 1831 & $\begin{array}{l}\text { Na+-translocating } \\
\text { NADH:ubiquinone oxido- } \\
\text { reductase NqrA }\end{array}$ & & & 220 & 2 \\
\hline 1833 & $\begin{array}{l}\text { Na+-translocating } \\
\text { NADH:ubiquinone } \\
\text { oxidoreductase NqrC }\end{array}$ & + & + & 106 & \\
\hline 4399 & Quinone oxidoreductase & & & 185 & 1 \\
\hline 7084 & Pyrophosphatase & & & 165 & \\
\hline 10215 & $\begin{array}{l}\text { H+-transporting ATP syn- } \\
\text { thase alpha chain }\end{array}$ & & + & 124 & 2 \\
\hline 10217 & $\begin{array}{l}\mathrm{H}+\text {-transporting ATP syn- } \\
\text { thase beta chain }\end{array}$ & & + & 307 & 2 \\
\hline 11946 & $\begin{array}{l}\text { Thermophilic NAD(P)H-flavin } \\
\text { oxidoreductase }\end{array}$ & & & 125 & 2 \\
\hline \multirow[t]{2}{*}{11985} & Quinone oxidoreductase & & & 191 & 1 \\
\hline & Others (8 proteins) & & & & \\
\hline 3895 & Internalin & + & & 93 & \\
\hline 4879 & Nodulin-26 & & & 117 & 1 \\
\hline 10228 & $\begin{array}{l}\text { Twitching motility protein } \\
\text { PilB, biogenesis of pili }\end{array}$ & & + & 118 & \\
\hline 10338 & $\begin{array}{l}\text { FlbA protein, biogenesis of } \\
\text { flagellae }\end{array}$ & & & 88 & \\
\hline 10463 & Ferredoxin-NADP reductase & & & 145 & \\
\hline 10905 & Phosphoesterase PH1616 & & + & 132 & 1 \\
\hline 10907 & Phosphoesterase PH1616 & & & 143 & 2 \\
\hline \multirow[t]{2}{*}{12774} & $\begin{array}{l}\text { Type IV fimbrial assembly } \\
\text { protein PilB }\end{array}$ & & & 269 & 1 \\
\hline & \multicolumn{5}{|c|}{ Conserved Hypothetical Proteins (94 proteins) } \\
\hline 85 & $\begin{array}{l}\text { Conserved hypothetical } \\
\text { protein }\end{array}$ & + & & 114 & \\
\hline 452 & $\begin{array}{l}\text { Conserved hypothetical } \\
\text { protein }\end{array}$ & & & 215 & 1 \\
\hline 457 & $\begin{array}{l}\text { Conserved hypothetical } \\
\text { protein }\end{array}$ & & & 183 & \\
\hline 520 & $\begin{array}{l}\text { Conserved hypothetical } \\
\text { protein }\end{array}$ & & & 145 & 1 \\
\hline 538 & $\begin{array}{l}\text { Conserved hypothetical } \\
\text { protein }\end{array}$ & & & 232 & 2 \\
\hline
\end{tabular}

Table 2. Continued

\begin{tabular}{|c|c|c|c|c|c|}
\hline ORF & Putative Function & $\mathrm{sp}$ & PHX & Score & $*$ \\
\hline 569 & $\begin{array}{l}\text { Conserved hypothetical } \\
\text { protein }\end{array}$ & + & + & 74 & 2 \\
\hline 1044 & $\begin{array}{l}\text { Conserved hypothetical } \\
\text { protein }\end{array}$ & & & 221 & 1 \\
\hline 1109 & $\begin{array}{l}\text { Conserved hypothetical } \\
\text { protein }\end{array}$ & + & + & 70 & 2 \\
\hline 1703 & Maf protein & & & 56 & \\
\hline 1731 & $\begin{array}{l}\text { Conserved hypothetical } \\
\text { protein }\end{array}$ & & & 75 & \\
\hline 1739 & $\begin{array}{l}\text { Conserved hypothetical } \\
\text { protein }\end{array}$ & & & 67 & \\
\hline 1753 & $\begin{array}{l}\text { Conserved hypothetical } \\
\text { protein }\end{array}$ & & + & 76 & 2 \\
\hline 1854 & $\begin{array}{l}\text { Conserved hypothetical } \\
\text { protein }\end{array}$ & & & 144 & \\
\hline 2435 & $\begin{array}{l}\text { Conserved hypothetical } \\
\text { protein }\end{array}$ & + & & 157 & \\
\hline 2680 & $\begin{array}{l}\text { Conserved hypothetical } \\
\text { protein }\end{array}$ & + & & 91 & 1 \\
\hline 2714 & $\begin{array}{l}\text { Conserved hypothetical } \\
\text { protein }\end{array}$ & & & 122 & \\
\hline 2908 & $\begin{array}{l}\text { Conserved hypothetical } \\
\text { protein }\end{array}$ & + & & 76 & \\
\hline 2912 & $\begin{array}{l}\text { Conserved hypothetical } \\
\text { protein }\end{array}$ & + & & 143 & 2 \\
\hline 2976 & $\begin{array}{l}\text { Conserved hypothetical } \\
\text { protein }\end{array}$ & & & 102 & \\
\hline 3221 & $\begin{array}{l}\text { Conserved hypothetical } \\
\text { protein }\end{array}$ & & & 161 & \\
\hline 3509 & $\begin{array}{l}\text { Conserved hypothetical } \\
\text { protein }\end{array}$ & + & & 183 & \\
\hline 3599 & Ring canal kelch protein & + & & 133 & \\
\hline 3924 & $\begin{array}{l}\text { Conserved hypothetical } \\
\text { protein }\end{array}$ & & & 107 & 1 \\
\hline 3944 & $\begin{array}{l}\text { Conserved hypothetical } \\
\text { protein }\end{array}$ & & + & 167 & 2 \\
\hline 4127 & $\begin{array}{l}\text { Conserved hypothetical } \\
\text { protein }\end{array}$ & + & & 99 & \\
\hline 4129 & $\begin{array}{l}\text { Conserved hypothetical } \\
\text { protein }\end{array}$ & & + & 105 & 2 \\
\hline 4278 & $\begin{array}{l}\text { Conserved hypothetical } \\
\text { protein }\end{array}$ & & & 81 & \\
\hline 4347 & $\begin{array}{l}\text { Conserved hypothetical } \\
\text { protein }\end{array}$ & & + & 109 & \\
\hline 4485 & $\begin{array}{l}\text { Conserved hypothetical } \\
\text { protein }\end{array}$ & & & 86 & 2 \\
\hline 4532 & $\begin{array}{l}\text { Conserved hypothetical } \\
\text { protein }\end{array}$ & + & & 83 & \\
\hline 4738 & $\begin{array}{l}\text { Conserved hypothetical } \\
\text { protein }\end{array}$ & & & 130 & 2 \\
\hline 4742 & $\begin{array}{l}\text { Conserved hypothetical } \\
\text { protein }\end{array}$ & & & 89 & 1 \\
\hline 5186 & $\begin{array}{l}\text { Conserved hypothetical } \\
\text { protein }\end{array}$ & & & 55 & 1 \\
\hline 5313 & $\begin{array}{l}\text { Conserved hypothetical } \\
\text { protein }\end{array}$ & & + & 157 & \\
\hline
\end{tabular}


Table 2. Continued

\begin{tabular}{|c|c|c|c|c|c|}
\hline ORF & Putative Function & $\mathrm{sp}$ & $\mathrm{PHX}$ & Score & * \\
\hline 5511 & $\begin{array}{l}\text { Conserved hypothetical } \\
\text { protein }\end{array}$ & & & 161 & \\
\hline 5788 & $\begin{array}{l}\text { Conserved hypothetical } \\
\text { protein }\end{array}$ & + & + & 58 & \\
\hline 5952 & $\begin{array}{l}\text { Conserved hypothetical } \\
\text { protein }\end{array}$ & + & & 133 & \\
\hline 6120 & TolB protein & + & & 105 & 2 \\
\hline 6395 & $\begin{array}{l}\text { Conserved hypothetical } \\
\text { protein }\end{array}$ & & & 65 & 2 \\
\hline 6409 & $\begin{array}{l}\text { Conserved hypothetical } \\
\text { protein }\end{array}$ & + & & 113 & \\
\hline 6416 & $\begin{array}{l}\text { Conserved hypothetical } \\
\text { protein }\end{array}$ & & & 133 & 1 \\
\hline 6417 & $\begin{array}{l}\text { Conserved hypothetical } \\
\text { protein }\end{array}$ & & & 81 & 2 \\
\hline 6530 & $\begin{array}{l}\text { Conserved hypothetical } \\
\text { protein }\end{array}$ & & & 70 & \\
\hline 7091 & $\begin{array}{l}\text { Conserved hypothetical } \\
\text { protein }\end{array}$ & & & 84 & \\
\hline 7120 & $\begin{array}{l}\text { Conserved hypothetical } \\
\text { protein }\end{array}$ & + & & 102 & 1 \\
\hline 7292 & $\begin{array}{l}\text { Conserved hypothetical } \\
\text { protein }\end{array}$ & & & 86 & \\
\hline 7538 & $\begin{array}{l}\text { Conserved hypothetical } \\
\text { protein }\end{array}$ & & + & 158 & 1 \\
\hline 7619 & $\begin{array}{l}\text { Conserved hypothetical } \\
\text { protein }\end{array}$ & & & 79 & 2 \\
\hline 7789 & TolB protein [precursor] & & & 61 & \\
\hline 7822 & $\begin{array}{l}\text { Conserved hypothetical } \\
\text { protein }\end{array}$ & & & 96 & 2 \\
\hline 8031 & $\begin{array}{l}\text { Conserved hypothetical } \\
\text { protein }\end{array}$ & + & & 122 & 1 \\
\hline 8188 & $\begin{array}{l}\text { Conserved hypothetical } \\
\text { protein }\end{array}$ & & & 58 & \\
\hline 8202 & $\begin{array}{l}\text { Conserved hypothetical } \\
\text { protein }\end{array}$ & & + & 86 & \\
\hline 8246 & $\begin{array}{l}\text { Conserved hypothetical } \\
\text { protein }\end{array}$ & + & & 184 & 2 \\
\hline 8266 & $\begin{array}{l}\text { Conserved hypothetical } \\
\text { protein }\end{array}$ & & + & 60 & 1 \\
\hline 8291 & $\begin{array}{l}\text { Conserved hypothetical } \\
\text { protein }\end{array}$ & & & 53 & \\
\hline 8456 & $\begin{array}{l}\text { Conserved hypothetical } \\
\text { protein }\end{array}$ & & & 73 & \\
\hline 8501 & $\begin{array}{l}\text { Conserved hypothetical } \\
\text { protein }\end{array}$ & + & & 158 & \\
\hline 8557 & $\begin{array}{l}\text { Conserved hypothetical } \\
\text { protein }\end{array}$ & & & 130 & \\
\hline 8565 & $\begin{array}{l}\text { Conserved hypothetical } \\
\text { protein }\end{array}$ & & + & 136 & 2 \\
\hline 8639 & $\begin{array}{l}\text { Conserved hypothetical } \\
\text { protein }\end{array}$ & + & & 168 & 2 \\
\hline 8677 & $\begin{array}{l}\text { Conserved hypothetical } \\
\text { protein }\end{array}$ & & & 152 & \\
\hline 8783 & $\begin{array}{l}\text { Conserved hypothetical } \\
\text { protein }\end{array}$ & & & 102 & \\
\hline
\end{tabular}

Table 2. Continued

\begin{tabular}{|c|c|c|c|c|c|}
\hline ORF & Putative Function & sp & PHX & Score & * \\
\hline 9132 & $\begin{array}{l}\text { Conserved hypothetical } \\
\text { protein }\end{array}$ & & + & 138 & 2 \\
\hline 9261 & $\begin{array}{l}\text { Conserved hypothetical } \\
\text { protein }\end{array}$ & & + & 139 & \\
\hline 9262 & $\begin{array}{l}\text { Conserved hypothetical } \\
\text { protein }\end{array}$ & & + & 113 & 1 \\
\hline 9367 & $\begin{array}{l}\text { Conserved hypothetical } \\
\text { protein }\end{array}$ & + & & 64 & \\
\hline 9386 & FixW protein & + & + & 64 & 2 \\
\hline 9438 & $\begin{array}{l}\text { Conserved hypothetical } \\
\text { protein }\end{array}$ & + & & 134 & 2 \\
\hline 9546 & $\begin{array}{l}\text { Conserved hypothetical } \\
\text { protein }\end{array}$ & + & & 91 & 1 \\
\hline 9606 & $\begin{array}{l}\text { Conserved hypothetical } \\
\text { protein }\end{array}$ & + & & 78 & \\
\hline 9849 & $\begin{array}{l}\text { Conserved hypothetical } \\
\text { protein }\end{array}$ & + & + & 175 & \\
\hline 9992 & $\begin{array}{l}\text { Conserved hypothetical } \\
\text { protein }\end{array}$ & & + & 151 & \\
\hline 10028 & $\begin{array}{l}\text { Conserved hypothetical } \\
\text { protein }\end{array}$ & & & 77 & 1 \\
\hline 10061 & $\begin{array}{l}\text { Conserved hypothetical } \\
\text { protein }\end{array}$ & & & 123 & 2 \\
\hline 10078 & $\begin{array}{l}\text { Conserved hypothetical } \\
\text { protein }\end{array}$ & + & & 299 & \\
\hline 10088 & $\begin{array}{l}\text { Conserved hypothetical } \\
\text { protein }\end{array}$ & & & 100 & 1 \\
\hline 10103 & $\begin{array}{l}\text { Conserved hypothetical } \\
\text { protein containing kelch- } \\
\text { motif }\end{array}$ & + & + & 102 & \\
\hline 10195 & $\begin{array}{l}\text { Conserved hypothetical } \\
\text { protein }\end{array}$ & + & + & 90 & 2 \\
\hline 10235 & $\begin{array}{l}\text { Conserved hypothetical } \\
\text { protein }\end{array}$ & & & 56 & \\
\hline 10359 & $\begin{array}{l}\text { Conserved hypothetical } \\
\text { protein }\end{array}$ & & & 129 & \\
\hline 10478 & $\begin{array}{l}\text { Conserved hypothetical } \\
\text { protein }\end{array}$ & + & & 140 & 2 \\
\hline 10789 & $\begin{array}{l}\text { Conserved hypothetical } \\
\text { protein }\end{array}$ & & + & 96 & \\
\hline 10987 & $\begin{array}{l}\text { Conserved hypothetical } \\
\text { protein }\end{array}$ & & & 113 & \\
\hline 11183 & $\begin{array}{l}\text { Conserved hypothetical } \\
\text { protein }\end{array}$ & & & 181 & 2 \\
\hline 11262 & $\begin{array}{l}\text { Conserved hypothetical } \\
\text { protein }\end{array}$ & & & 101 & 1 \\
\hline 11494 & $\begin{array}{l}\text { Conserved hypothetical } \\
\text { protein }\end{array}$ & + & & 60 & \\
\hline 11505 & $\begin{array}{l}\text { Conserved hypothetical } \\
\text { protein }\end{array}$ & + & + & 68 & \\
\hline 11728 & $\begin{array}{l}\text { Conserved hypothetical } \\
\text { protein }\end{array}$ & & + & 177 & 2 \\
\hline 11811 & $\begin{array}{l}\text { Conserved hypothetical } \\
\text { protein }\end{array}$ & + & & 70 & \\
\hline 11998 & $\begin{array}{l}\text { Conserved hypothetical } \\
\text { protein }\end{array}$ & + & + & 156 & 2 \\
\hline
\end{tabular}


Table 2. Continued

\begin{tabular}{|c|c|c|c|c|c|}
\hline ORF & Putative Function & $\mathrm{sp}$ & $\mathrm{PHX}$ & Score & * \\
\hline 12056 & $\begin{array}{l}\text { Conserved hypothetical } \\
\text { protein containing TPR } \\
\text { domain }\end{array}$ & + & & 281 & 2 \\
\hline 12301 & $\begin{array}{l}\text { Conserved hypothetical } \\
\text { protein }\end{array}$ & + & + & 79 & \\
\hline 12891 & $\begin{array}{l}\text { Conserved hypothetical } \\
\text { protein }\end{array}$ & & & 95 & \\
\hline
\end{tabular}

\section{Hypothetical Proteins (98 proteins)}

14 Hypothetical protein

68 Hypothetical protein

404 Hypothetical protein

512 Hypothetical protein

1002 Hypothetical protein

1088 Hypothetical protein

1260 Hypothetical protein

1352 Hypothetical protein

1535 Hypothetical protein

1599 Hypothetical protein

1828 Hypothetical protein

2088 Hypothetical protein

2166 Hypothetical protein

2436 Hypothetical protein

2448 Hypothetical protein

2501 Hypothetical protein

2647 Hypothetical protein

2782 Hypothetical protein

2822 Hypothetical protein

2830 Hypothetical protein

2901 Hypothetical protein

3060 Hypothetical protein

3320 Hypothetical protein

3346 Hypothetical protein

3437 Hypothetical protein

3479 Hypothetical protein

3500 Hypothetical protein

3504 Hypothetical protein

3513 Hypothetical protein

3577 Hypothetical protein

3764 Hypothetical protein

4041 Hypothetical protein

4182 Hypothetical protein

4256 Hypothetical protein

4464 Hypothetical protein

4703 Hypothetical protein

4931 Hypothetical protein

5031 Hypothetical protein

5240 Hypothetical protein

5268 Hypothetical protein

5310 Hypothetical protein

5734 Hypothetical protein

5763 Hypothetical protein

5794 Hypothetical protein

5811 Hypothetical protein

5938 Hypothetical protein

5945 Hypothetical protein
Table 2. Continued

\begin{tabular}{|c|c|c|c|c|c|}
\hline ORF & Putative Function & $\mathrm{sp}$ & $\mathrm{PHX}$ & Score & * \\
\hline 6051 & Hypothetical protein & & & 90 & \\
\hline 6127 & Hypothetical protein & + & & 105 & 2 \\
\hline 6162 & Hypothetical protein & & + & 66 & \\
\hline 6221 & Hypothetical protein & + & & 161 & 2 \\
\hline 6400 & Hypothetical protein & + & & 103 & 1 \\
\hline 6610 & Hypothetical protein & & + & 370 & \\
\hline 6658 & Hypothetical protein & + & + & 160 & 2 \\
\hline 6713 & Hypothetical protein & & & 164 & 2 \\
\hline 6771 & Hypothetical protein & + & & 220 & \\
\hline 6888 & Hypothetical protein & + & & 130 & 2 \\
\hline 6941 & Hypothetical protein & + & + & 52 & \\
\hline 7203 & Hypothetical protein & & + & 157 & 2 \\
\hline 7235 & Hypothetical protein & + & + & 194 & \\
\hline 7476 & Hypothetical protein & + & & 95 & \\
\hline 7801 & Hypothetical protein & & & 70 & \\
\hline 8337 & Hypothetical protein & & & 144 & \\
\hline 8750 & Hypothetical protein & + & & 112 & \\
\hline 8980 & Hypothetical protein & + & & 106 & \\
\hline 9034 & Hypothetical protein & + & & 176 & \\
\hline 9101 & Hypothetical protein & + & & 108 & 2 \\
\hline 9512 & Hypothetical protein & + & & 82 & 1 \\
\hline 9518 & Hypothetical protein & + & & 65 & \\
\hline 9527 & Hypothetical protein & + & + & 215 & 1 \\
\hline 9742 & Hypothetical protein & & & 86 & \\
\hline 9798 & Hypothetical protein & & + & 110 & \\
\hline 9867 & Hypothetical protein & & & 107 & \\
\hline 9973 & Hypothetical protein & & & 118 & \\
\hline 10075 & Hypothetical protein & & & 103 & \\
\hline 10460 & Hypothetical protein & + & & 89 & 1 \\
\hline 10530 & Hypothetical protein & & & 128 & \\
\hline 10823 & Hypothetical protein & + & & 143 & 2 \\
\hline 10835 & Hypothetical protein & & & 275 & 1 \\
\hline 11008 & Hypothetical protein & + & & 242 & 2 \\
\hline 11575 & Hypothetical protein & + & & 92 & 1 \\
\hline 12035 & Hypothetical protein & & & 120 & 2 \\
\hline 12167 & Hypothetical protein & & + & 124 & 1 \\
\hline 12219 & Hypothetical protein & & & 91 & \\
\hline 12416 & Hypothetical protein & + & & 162 & 1 \\
\hline 12442 & Hypothetical protein & & & 165 & \\
\hline 12461 & Hypothetical protein & + & + & 154 & 2 \\
\hline 12489 & Hypothetical protein & + & & 113 & \\
\hline 12630 & Hypothetical protein & + & & 90 & 2 \\
\hline 12645 & Hypothetical protein & & + & 114 & \\
\hline 12702 & Hypothetical protein & + & & 62 & \\
\hline 12787 & Hypothetical protein & & & 168 & 2 \\
\hline 12808 & Hypothetical protein & + & & 95 & \\
\hline 12844 & Hypothetical protein & & & 134 & 2 \\
\hline 12897 & Hypothetical protein & + & & 62 & \\
\hline 12968 & Hypothetical protein & + & & 119 & 1 \\
\hline 13231 & Hypothetical protein & & & 105 & \\
\hline 13319 & Hypothetical protein & & + & 102 & \\
\hline
\end{tabular}

a) The quality of the mass spectrometric protein identification results are characterized by their probability-based MOWSE scores (Score), and the number of gels, in which a protein was identified $(*)$. The presence of a predicted signal peptide (sp) and the predicted level of gene expression (PHX) are provided. Listed are the proteins that received scores $>51$, corresponding to $95 \%$ confidence (for details, see text). 
Table 3. Proteins (new ORF) specifically identified from the Maximal ORF Set (MOS)

\begin{tabular}{|c|c|c|c|c|c|c|}
\hline ORF no. & Start & Stop & $\begin{array}{l}\text { Length } \\
\text { (aa) }\end{array}$ & $\begin{array}{l}\text { MASCOT } \\
\text { score }\end{array}$ & $\begin{array}{l}\text { Predicted } \\
\text { function }\end{array}$ & Genetic context \\
\hline pir.6532c & 1798993 & 1799565 & 290 & 61 & Hypothetical & $\begin{array}{l}\text { Methionine aminopeptidase, } \\
\text { hypotheticals; other strand: } \\
\text { ribose-regulated sugar-ADH }\end{array}$ \\
\hline pir.8508 & 2358829 & 2359248 & 139 & 60 & Hypothetical & Mostly hypotheticals \\
\hline pir.9191c & 2546400 & 2546921 & 173 & 101 & Hypothetical & $\begin{array}{l}\text { Mostly hypotheticals, down- } \\
\text { stream of possible adenylate } \\
\text { cyclase }\end{array}$ \\
\hline pir.15895 & 4437587 & 4438426 & 279 & 56 & Hypothetical & $\begin{array}{l}\text { Mostly hypotheticals; upstream } \\
\text { of D-tyrosyl-tRNA(Tyr)- } \\
\text { deacylase }\end{array}$ \\
\hline
\end{tabular}

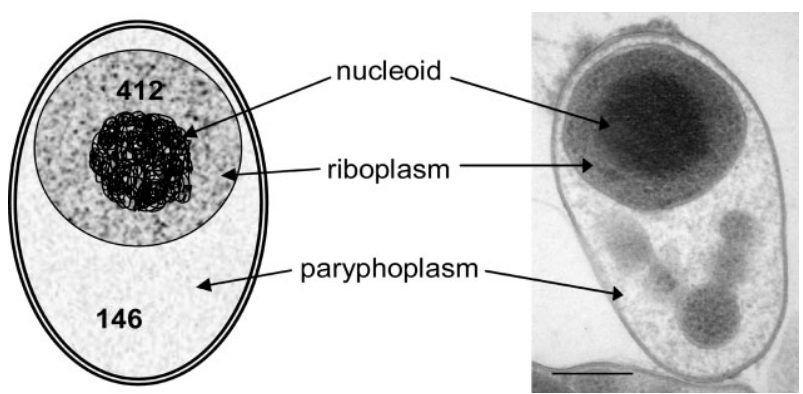

Figure 3. Intracellular compartmentalization of $R$. baltica and possible location of identified proteins ( $B a r=0.2 \mu \mathrm{m}$ ).

According to the signal hypothesis [46], the majority of secreted proteins have a signal peptide, which is found in $1160(16 \%)$ of the predicted proteins in R. baltica. Out of the 558 identified proteins annotated in the master gel 146 (26\%) possess a signal peptide (Table 2). Since the applied methods for cell breakage did not separate riboplasmic from paryphoplasmic proteins one can conclude that the 146 signal peptide containing proteins have potentially been secreted and are actually localized in the paryphoplasm or are cell wall associated.

For $58 \%$ (57 proteins) of the hypothetical proteins a signal peptide was predicted. Thirty-six (about 38\%) of the 94 conserved hypothetical proteins are secreted according to the signalP prediction. Secreted proteins with functional assignment are mainly dehydrogenases, hydrolases for extracellular macromolecules or involved in signal transduction (phosphoprotein kinases). In contrast, the enzymes performing housekeeping functions seem to be confined to the riboplasm (no signal peptide). Interestingly, nine of the 10 identified sulfatases have a signal peptide prediction. The $R$. baltica genome encodes 110 sulfatases, which are suggested to function in extracellular degradation of sulfated glycopolymers such as, e.g., carrageen [26]. Thus, the identified sulfatases could be in the process of being excreted, since proteins already excreted to the extracellular space would have been lost under the applied conditions of cell harvesting. Expression of sulfatase encoding genes might not require the presence of sulfated substrates, since the studied $R$. baltica cells were grown with ribose as only source of organic carbon. In some cases the correctness of the signal peptide prediction is questionable, e.g., for the elongation factor $\mathrm{G}$ and lysyl-tRNA synthase. Both enzymes play an important role in protein synthesis, a process that should exclusively take place in the riboplasm. Thus the presence of a signal peptide alone does not allow defining the exact target region of translocation. Future research on secreted proteins (secretome) will have to differentiate the different compartments present in R. baltica cells.

\subsection{Predicted highly expressed (PHX) genes}

Among the 30 most abundant proteins on the master gel of $R$. baltica, 27 were encoded by genes that were predicted to be highly expressed (PHX) according to codon usage adaptation. Thus, a correlation between experimentally determined protein abundance and codon usage features as it already has been shown for fast-growing bacteria [43] could also be observed for R. baltica, a slowly growing environmental bacterium (doubling times between 10-14 h, [32]). However, there are some exceptions where the genes of proteins appearing as highly abundant on 2-DE gels are not PHX; this applies mainly for proteins that were, e.g., specifically induced during growth with ribose (see accompanying publication) or proteins affiliated with lipid metabolism.

\section{Concluding remarks}

With more than 550 identified gene products, the present study established a solid proteomic framework for further analysis of differential gene expression in $R$. baltica. Considering the nutritional specialization of this bacterium on the utilization of carbohydrates, we will be able to reconstruct the major catabolic routes which are operative in $R$. baltica and to learn about the potential of this bacterium to regulate 
the expression of catabolic genes in response to the availability of respective growth substrates (see accompanying publication). The master gel will also be beneficial for the identification of proteins involved in cell cycle and development. Such proteins should be related to the two morphotypes (single cells versus aggregates) as well as to different growth stages.

We thank Alfred Beck and Thomas Kreitler for bioinformatics support. We are indebted to Friedrich Widdel for continuous support of proteomic work at the MPI in Bremen. This study was supported by the Max Planck Society.

\section{Addendum in proof}

A recent proteomic study revealed growth phase dependent regulation of protein composition in $R$. baltica (Gade, D., Stührmann, T., Reinhardt, R., Rabus, R., Environ. Microbiol. 2005, 7, 1074-1084).

\section{References}

[1] Fleischmann, R. D., Adams, M. D., White, O., Clayton, R. A. et al., Science 1995, 269, 496-512.

[2] Himmelreich, R., Hilbert, H., Plagens, H., Pirkl, E. et al., Nucleic. Acids Res. 1996, 24, 4420-4449.

[3] Tonella, L., Walsh, B. J., Sanchez, J. C., Ou, K., et al., Electrophoresis 1998, 19, 1960-1971.

[4] Tonella, L., Hoogland, C., Binz, P.-A., Appel, R. D. et al., Proteomics 2001, 1, 409-423.

[5] Molloy, M. P., Herbert, B. R., Slade, M. B., Rabilloud, T. et al., Eur. J. Biochem. 2000, 276, 2871-2881.

[6] Ohlmeier, S., Scharf, C., Hecker, M., Electrophoresis 2000, 21, 3701-3709.

[7] Büttner, K., Bernhardt, J., Scharf, C., Schmid, R. et al., Electrophoresis 2001, 22, 2908-2935.

[8] Regula, J. T., Ueberle, B., Boguth, G., Görg, A. et al., Electrophoresis 2000, 21, 3765-3780.

[9] Regula, J. T., Boguth, G., Görg, A., Mayer, F. et al., Microbiology 2001, 147, 1045-1057.

[10] Ueberle, B., Frank, R., Herrmann, R., Proteomics 2002, 2, 754-764.

[11] Cordwell, S. J., Larsen, M. R., Cole, R. T., Walsh, B. J., Microbiology, 2002, 148, 2765-2781.

[12] Hecker, M., Engelmann, S., Cordwell, S. L., J. Chromatogr. $B$ 2003, 787, 179-195.

[13] Fountoulakis, M., Takacs, B., Langen, H., Electrophoresis 1998, 19, 761-766.

[14] Fountoulakis, M., Juranville, J. F., Roder, D., Evers, S. et al., Electrophoresis 1998, 19, 1819-1827.

[15] Langen, H., Takács, B., Evers, S., Berndt, P. et al., Electrophoresis 2000, 21, 411-429.

[16] Nouwens, A. S., Willcox, M. D., Walsh, B. J., Cordwell, S. J., Proteomics 2002, 2, 1325-1346.
[17] Hermann, T., Pfefferle, W., Baumann, C., Busker, E. et al., Electrophoresis 2001, 22, 1712-1723.

[18] Hesketh, A. R., Chandra, G., Shaw, A. D., Rowland, J. J. et al., Mol. Microbiol. 2002, 46, 917-932.

[19] Görg, A., Obermaier, C., Boguth, G., Harder, A. et al., Electrophoresis 2000, 21, 1037-1053.

[20] Pappin, D. J. C., Højrup, P., Bleasby, A. J., Curr. Biol. 1993, 3, 327-332.

[21] Henzel, W.J., Billeci, T.M., Stults, J.T., Wong, S.C. et al. Proc. Natl. Acad. Sci. USA 1993, 90, 5011-5015.

[22] Mann, M., Højrup, P., Roepstorff, P., Biol. Mass Spectrom. 1993, 22, 338-345.

[23] Karas, M., Hillenkamp, F., Anal. Chem. 1988, 60, 2301-2303.

[24] Kaneko, T., Sato, S., Kotani, H., Tanaka, A. et al., DNA Res. 1996, 3, 109-136.

[25] Nierman, W. C, Feldblyum, T. V., Laub, M. T., Paulsen, I. T. et al., Proc. Natl. Acad. Sci. USA 2001, 98, 4136-4141.

[26] Glöckner, F. O., Kube, M., Bauer, M., Teeling, H. et al., Proc. Natl. Acad. Sci. USA 2003, 100, 8298-8303.

[27] Vohradsky, J., Janda, I., Grünenfelder, B., Berndt, P. et al., Proteomics 2003, 3, 1874-1882.

[28] Huang, F., Parmryd, I., Nilsson, F., Persson, A. L. et al., Mol. Cell. Proteomics 2002, 1, 956-966.

[29] Schlesner, H., Bartels, C., Tindall, B. J., Gade, D. et al., Int. J. Syst. Evol. Microbiol. 2004, 54, 1567-1580.

[30] Lindsay, M., Webb, R. I., Fuerst, J. A., Microbiology 1997, 143, 739-748.

[31] Lindsay, M., Webb, R. I., Strous, M., Jetten, M. S. M. et al., Arch. Microbiol. 2001, 175, 413-429.

[32] Rabus, R., Gade, D., Helbig, R., Bauer, M. et al., Proteomics 2002, 2, 649-655.

[33] Bradford, M. M., Anal. Biochem. 1976, 72, 248-254.

[34] Gade, D., Thiermann, J., Markowsky, D., Rabus, R., J. Mol. Microbiol. Biotechnol. 2003, 5, 240-251.

[35] Dorothy, N. S., Littmann, B. H., Reilly, K., Swindell, A. C., Buss, J. M., Anderson, N. L., Electrophoresis 1998, 19, 355363.

[36] Nordhoff, E., Egelhofer, V., Giavalisco, P., Eickhoff, H. et al., Electrophoresis 2001, 22, 2844-2855.

[37] Gobom, J., Schuerenberg, M., Mueller, M., Theiss, D. et al., Analyt. Chem. 2001, 73, 434-438.

[38] Gobom, J., Mueller, M., Egelhofer, V., Theiss, D. et al., Anal. Chem. 2002, 74, 3915-3923.

[39] Perkins, D. N., Pappin, D. J., Creasy, D. M., Cottrell, J. S., Electrophoresis 1999, 20, 3551-3567.

[40] Rice, P., Longden, I., Bleasby, A., Trends Genet. 2000, 16, 276-277.

[41] Nielsen, H., Engelbrecht, J., Brunak, S., von Heijne, G., Protein Eng. 1997, 10, 1-6.

[42] Meyer, F., Goesmann, A., McHardy, A. C., Bartels, D. et al., Nucleic Acids Res. 2003, 31, 2187-2195.

[43] Karlin, S., Mrázek, J., Campell, A., Kaiser, D., J. Bacteriol. 2001, 183, 5025-5040.

[44] VanBogelen, R. A., Schiller, E. E., Thomas, J. D., Neidhardt, F. C., Electrophoresis 1999, 20, 2149-2159.

[45] Schwartz, R., Ting, C. S., King, J., Genome Res. 2001, 11, 703-709.

[46] Blobel, G., Chembiochemistry 2000, 1, 86-102. 